\title{
Essential contribution of caspase 3/CPP32 to apoptosis and its associated nuclear changes
}

\author{
Minna Woo, ${ }^{1,4}$ Razqal lah Hakem, ${ }^{1,4}$ Maria S. Soengas, ${ }^{2,4}$ Gordon S. Duncan, ${ }^{1}$ Arda Shahinian, ${ }^{1}$ \\ David Kägi, ${ }^{1}$ Anne Hakem, ${ }^{1}$ Mila McCurrach, ${ }^{2}$ Wilson Khoo, ${ }^{1,2}$ Stephen A. Kaufman, ${ }^{3}$ Giorgio \\ Senal di, ${ }^{3}$ Tamara Howard, ${ }^{2}$ Scott W. Lowe, ${ }^{2}$ and Tak W. Mak ${ }^{1,5}$ \\ ${ }^{1}$ Amgen Institute Ontario Cancer Institute, Department of M edical Biophysics and Immunology, University of Toronto, \\ Toronto, Ontario M 5G 2C 1, Canada; ${ }^{2}$ Cold Spring Harbor Laboratory, Cold Spring Harbor, N ew York 11724 USA; ${ }^{3}$ Amgen, \\ Inc., Thousand Oaks, CA 91320-1789 USA
}

Caspases are fundamental components of the mammalian apoptotic machinery, but the precise contribution of individual caspases is controversial. CPP32 (caspase 3) is a prototypical caspase that becomes activated during apoptosis. In this study, we took a comprehensive approach to examining the role of CPP32 in apoptosis using mice, embryonic stem (ES) cells, and mouse embryonic fibroblasts (MEFs) deficient for CPP32. CPP32 mice have reduced viability and, consistent with an earlier report, display defective neuronal apoptosis and neurological defects. Inactivation of C PP32 dramatically reduces apoptosis in diverse settings, including activation-induced cell death (AICD) of peripheral T cells, as well as chemotherapy-induced apoptosis of oncogenically transformed CPP32 ${ }^{-1-}$ MEFs. As well, the requirement for CPP32 can be remarkably stimulus-dependent: In ES cells, CPP32 is necessary for efficient apoptosis following UV- but not $\gamma$-irradiation. Conversely, the same stimulus can show a tissue-specific dependence on CPP32: Hence, TNF $\alpha$ treatment induces normal levels of apoptosis in CPP32 deficient thymocytes, but defective apoptosis in oncogenically transformed MEFs. Finally, in some settings, CPP32 is required for certain apoptotic events but not others: Select CPP32 $2^{\mathrm{ex}-1-}$ cell types undergoing cell death are incapable of chromatin condensation and DNA degradation, but display other hallmarks of apoptosis. Together, these results indicate that CPP32 is an essential component in apoptotic events that is remarkably system- and stimulus-dependent. Consequently, drugs that inhibit CPP32 may preferentially disnupt specific forms of cell death.

[Key Words: Apoptosis; caspase; CPP32; cell death; MEFs]

Received N ovember 3, 1997; revised version accepted January 9, 1998.

Programmed cell death (PCD), or apoptosis, is a basic feature of all nucleated animal cells and is essential for normal development and tissue homeostasis (Nagata 1997). Because apoptosis is under genetic control, mutations that disrupt apoptotic programs can produce diseases. For example, inappropriate or excessive cell death can lead to neurodegenerative disorders such as AIzheimer's or Huntington's disease, whereas reductions in cell death contribute to lymphoprol iferative di sorders or neoplasia (Green and Martin 1995; Steller 1995; Goldberg et al. 1996). M any toxic agents, including most compounds used to treat cancer, induce apoptosis (M esner et al. 1997). Hence, factors that influence apoptotic cell death may contribute to the outcome of cancer therapy. Because dysregulation of apoptosis contributes to a variety of human disorders (Thompson 1995), compounds

4These authors contributed equally to this paper.

${ }^{5}$ Corresponding author.

E-MAIL tmak@uci.utoronto.ca; FAX (416) 204-5300. that promote or inhibit specific forms of apoptosis may be of considerable therapeutic value.

Important insights into the molecular control of apoptosis have come from studies of the nematode Caenorhabditis elegans (Hengartner and Horvitz 1994a; Hengartner 1996). For example, loss-of-function mutations in ced9 lead to inappropriate cell death, whereas gain-of-function mutations block virtually all cell death. In contrast, loss-of-function mutations of either ced3 or ced4 result in a global suppression of cell death, implying that these genes encode key components of the celIular machinery required for PCD. Counterparts to each of these $C$. el egans genes have been identified in mammalian systems. bcl 2 is homologous to ced9, ced3 is related to interleukin-1 $\beta$ converting enzyme (ICE), and recently, A paf1 has been shown to be homologous to ced 4 (Yuan et al. 1993; Hengartner and Horvitz 1994b; Vaux et al. 1996; Zhou et al . 1997). Despi tethis conservation, the complexity of apoptotic control in mammalian systems appears to be far greater than in $\mathrm{C}$. elegans, even at the level of the central cell death machinery. bcl 2 is a mem- 
ber of a much larger gene family that includes proteins that both promote and inhibit cell death (Reed 1997). Furthermore, at least 10 members of the ICE gene family, now called caspases, have been identified (Alnemri et al. 1996).

Considerable evidence suggests that, as in C. el egans, caspases are essential components of the mammalian cell death machinery (Steller 1995; Nicholson et al. 1995). Because the proteolytic cleavage of proteins is largely irreversible, activation of these enzymes may represent a rate-limiting step in apoptosis. Thus, elucidating the role and regulation of caspases is essential for a complete understanding of apoptosis. N evertheless, the existence of multiple caspases, often coexpressed in the same cell type and coactivated during apoptosis, raises several fundamental questions. Do the different caspases function in a tissue-specific manner? Can they participate in some forms of cell death but not others? Do individual caspases have specific tasks in the destruction of the cell, or are they functionally redundant? Finally, from a therapeutic perspective: Would the inhibition of key caspases have global effects on apoptosis or disrupt only certain forms of cell death?

Of the caspases identified to date, CPP32 (caspase 3 ) is closest in sequence homology and substrate specificity to the ced3 (Xue et al. 1996). Furthermore, CPP32 has been shown to be one of the major activated caspases present in apoptotic cells, suggesting that it plays a prominent role in the cell death process (Fal eiro et al. 1997). Despite this prediction, mice deficient for CPP32 were reported to have neuronal defects, but no other obvious developmental abnormalities were described (Kuida et al. 1996).

To better establish the role of CPP32 in various forms of apoptosis, we took a comprehensive approach toward evaluating the consequences of CPP32 deficiency in a variety of settings. To this end, we deleted exon 3 of the CPP32 gene and generated CPP32 $2^{\text {ex }}-1-$ mice as well as CPP32 $2^{\text {ex3-1- embryonic stem (ES) cells and CPP32 }} 2^{\text {ex }-1-}$ primary mouse embryonic fibroblasts (MEFs). We conclude that the requirement for CPP32 in apoptosis is tissue-specific and can even be stimulus-specific within the same cell type. Moreover, in select cell systems, CPP32 is strictly required for chromatin condensation and DN A degradation, but not for other features of apoptotic cell death. Consequently, these studies document the fundamental importance of CPP32 in many forms of apoptosis, and underscore the complexity of apoptotic control in mammalian systems. The remarkable variability with which inactivation of CPP32 affects apoptosis suggests that inhibitors that target CPP32-and perhaps other caspases as well-may have potential utility in blocking specific forms of cell death.

\section{Results}

Generation of CPP32 ${ }^{\mathrm{ex} 3}$ mutant cells and mice

The CPP32 gene was disrupted in ES cells by use of a targeting vector that deleted exon 3 of CPP32 gene, lead- ing to the introduction of termination codons in all three reading frames. The neomycin resistance gene (neo) was inserted in the targeting vector such that neo was flanked by $0.6 \mathrm{~kb}$ and $2.1 \mathrm{~kb}$ of genomic DN A $5^{\prime}$ and $3^{\prime}$ of CPP32 exon 3, respectively (Fig. 1A). The targeting construct was el ectroporated to ES cells, and three of 800

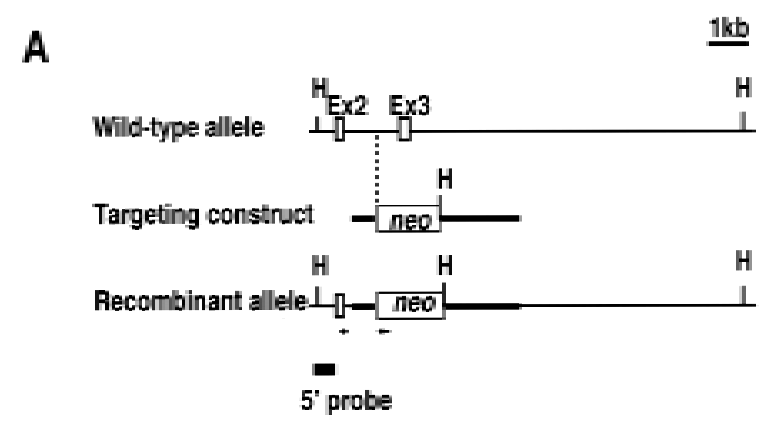

B

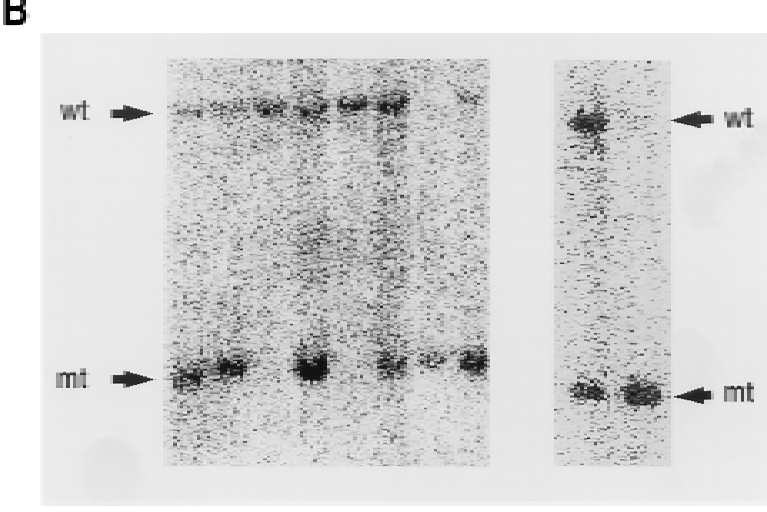

C

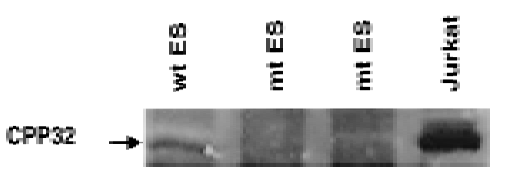

Figure 1. Targeted disruption of the CPP32 locus. (A) A 9.4-kb HindlII DNA fragment of the mouse CPP32 wild-type locus (top). Exon (Ex) 2 and 3 (open boxes) and HindlII (H) sites are shown. The targeting construct (middle) and the position of (neo), which replaces CPP32 exon 3. neo is flanked by 0.6-kb and 2.1-kb genomic DNA at the $5^{\prime}$ and $3^{\prime}$ ends of the CPP32 locus, respectively. The recombinant CPP $32^{\mathrm{ex} 3}$ allele (bottom) shows the 2.3-kb HindlII fragment present in the mutated allele. Positions of the primers and probe used to genotype the mutant are shown. (B) Southern bl ot analysis of representative genomic tail DNA from one litter of CPP32 ${ }^{\text {ex3 }}$ heterozygous intercrosses (left) and Southern bl ot analysis of DN A from heterozygous and homozygous CPP32 ${ }^{\mathrm{ex} 3}$ ES cells. DN A was digested with HindIII and hybridized with $5^{\prime}$ external probe. The 9.4-kb band representative of the CPP32 wild-type (wt) and the 2.3-kb band representative of the mutant CPP32 ${ }^{\text {ex3 }}$ allele $(\mathrm{mt})$ are indicated with arrows. (C) Western blot analysis of CPP32 expression. Cell extracts from wild-type (wt), two homozygous CPP32 ${ }^{\mathrm{ex}}$ (mt) ES cells, and Jurkat cells were electrophoresed on a $10 \%$ SDS-polyacrylamide gel, transferred to nitrocellulose, and hybridized with anti-human CPP32 antiserum. The arrow indicates that the CPP32 band is present in the wild-type ES and Jurkat cells but not in the two CPP32 ${ }^{\text {ex } 3-1-}$ ES cells. 
G418-resistant colonies analyzed by PCR and Southern blotting were found to be heterozygous at the CPP32 Iocus. Two of these ES cell clones were used to generate chimeric mice, and both successfully contributed to the germ line.

Chimeric mice derived from two independent heterozygous ES clones were backcrossed to C57BL/6J mice, and heterozygous mice were crossed to produce homozygous mutant offspring. CPP32 ${ }^{\text {ex } 3-1-}$ mice derived from the two CPP32 heterozygous ES cell clones were indistinguishable in phenotype and responses to apoptotic stimuli. The genotypes of the mice were confirmed by Southern blot analysis (Fig. 1B).

In anticipation of a potential early lethality of CPP32 mutant mice, and to study the role of CPP32 during ES cell apoptosis, we derived CPP $32^{\mathrm{ex} 3-1-E S}$ cells by selecting two CPP $32^{\mathrm{ex}+1-}$ clones at a higher G418 concentration and screening for loss of the wild-type allele (N ishina et al. 1997). One homozygous CPP32 ${ }^{\text {ex3 }}$ clone was obtained from each CPP32 ${ }^{\mathrm{ex} 3}$ heterozygous ES cell line (Fig. 1B). Western blot analysis with anti-human CPP32 antiserum indicated that the 32-kD CPP32 proenzyme was expressed in wild-type ES cells but not in CPP32 ${ }^{\text {ex3 }}$ homozygous ES cells (Fig. 1C).

To assess the role of CPP32 in thymocyte and peripheral $T$ cell development and apoptosis, the two

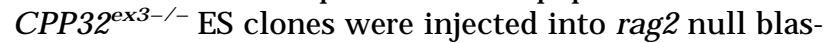
tocysts to generate somatic chimeras. rag $2^{-1-}$ mice reconstituted with either of the CPP32 $2^{\text {ex } 3-1-}$ ES cell clones showed similar results. CPP32 $2^{\mathrm{e} 3-1-}$ and control MEFs from day 12.5 of gestation were also derived to study the role of CPP32 in the apoptosis of both normal and transformed fibroblasts.

CPP $32^{\text {ex3 }}$ mutation affects embryonic devel opment and reduces mouse life span

CPP32 ${ }^{\mathrm{ex} 3}$ mutant mice were born at lower than the expected Mendelian frequency (9\%). Most survived until only 4-5 weeks of age. Consistent with the previously reported CPP32 mutant mice, our CPP32 ${ }^{\text {ex } 3-1-}$ mice were smaller than their littermates, showed neurological abnormalities, and had visible masses in their heads that represent ectopic masses of supernumerary cells in place of pyknotic clusters that represent normal apoptosis that occur during brain development (Kuida et al. 1996).

Lack of expression of CPP32 does not affect immature $T$ and $B$ cell development

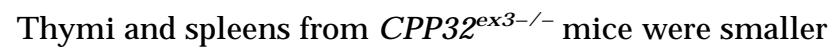
than in the wild type in proportion to their decreased overall body size. Thymi and spleens from CPP32 ${ }^{\text {ex3-1- }}$ mice contained normal distributions of the expected cell populations. Consistent with a previous report, apoptosis of thymic $T$ cells induced by CD $3 \epsilon$ crosslinking, antiCD95 (Fas), or dexamethasone was unaltered in the absence of CPP32, as was apoptosis in response to TNF $\alpha$ (data not shown).

To address the effect of CPP32 on immature B cell apoptosis, bone marrow cells from mutant and wild-type mice were treated with anti-IgM for 24 or $48 \mathrm{hr}$ and the apoptosis of $B 220^{+} \mathrm{CD} 43^{+}$immature $B$ cells was monitored with 7-Aminoactinomycin D (7-AAD) staining (Schmid et al. 1994). No apoptotic differences were observed in the treated immature $B$ cells in the absence of CPP32 expression (data not shown). Thus, CPP32 is not required during $T$ and $B$ cell differentiation.

CPP32 deficient peripheral T cells are less susceptible to AICD-, CD3 $\epsilon^{-}$, and CD95 (Fas)-induced apoptosis

Activated $T$ cells must be removed by apoptosis at the end of an immune response to maintain cellular homeostasis (Akbar et al. 1997). To determine the function of CPP32 in the activation-induced cell death (AICD) of peripheral $T$ cells, the responses of mature $T$ cells to several stimuli were examined. In response to $C D \epsilon-$ cross-linking, with either anti-CD28 mAb or IL2, wildtype as well as CPP32 ${ }^{\mathrm{ex} 3-1-\mathrm{T}}$ cells showed significant $\left[{ }^{3} \mathrm{H}\right]$ thymidi ne incorporation by 3 days after stimulation. The level of $\left[{ }^{3} \mathrm{H}\right]$ thymidine incorporation in the wild type, however, dropped by day 4 , but remained high in the mutant CPP32 ${ }^{\mathrm{e} 3-1-}$ cells (Fig. 2A).

To determine whether the increased $\left[{ }^{3} \mathrm{H}\right]$ thymidine incorporation observed in CPP32 $2^{\text {ex } 3-1-T}$ cells was caused by a defect in cell death, the wild-type and mutant

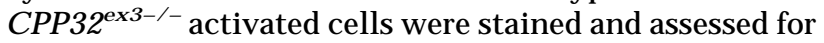
viability by trypan blue exclusion and by costaining with annexin V-FITC and propidium iodide (PI). Annexin V binds phophatidyl serine (PS) on the plasma membrane, allowing detection of the membrane disintegration, which is an early signature event in apoptosis (Fadok et al. 1992).

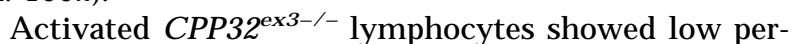
centages and numbers of dying cells compared with controls when anal yzed with 7-AAD staining and cell count by hemocytometer by trypan blue exclusion, respectively (Fig. 2B and data not shown). Similar results were obtained when activated $T$ Iymphocytes from rag2 ${ }^{-1-}$

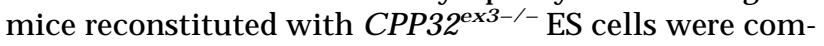
pared with activated $\mathrm{T}$ Iymphocytes derived from rag2 ${ }^{-1-}$ mice reconstituted with wild-type ES cells (Fig. 2C).

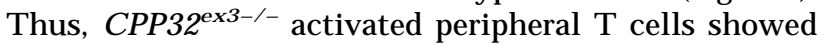
higher and more persi stent $\left[{ }^{3} \mathrm{H}\right]$ thymidine incorporation, likely the result of decreased cell death. Similarly, in response to superantigen staphylococcal enterotoxin $A$

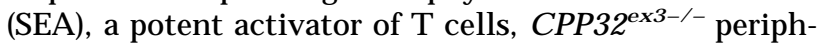
eral $\mathrm{T}$ lymphocytes showed greater and more persistent $\left[{ }^{3} \mathrm{H}\right]$ thymidine incorporation associated with reduced cell death compared with wild-type controls (Fig. 2B,D). These results are in keeping with the recent report that shows cystein inhibitors prevent activation induced peripheral T cell apoptosis (Y ang et al. 1997).

Peripheral T cells were also examined for their susceptibility to cell death by CD $3 \epsilon$ and CD95 antibody. Activated lymphocytes were treated for 24 and $48 \mathrm{hr}$ with CD3€ or CD95 antibody. Significant differences in viability were seen $24 \mathrm{hr}$ after CD $3 \epsilon$ crosslinking; $(27 \%$ and $46 \%$ viable cells in CPP32 $2^{\text {ex3+1- }}$ and CPP32 $2^{\text {ex3-1-T }}$ 
A

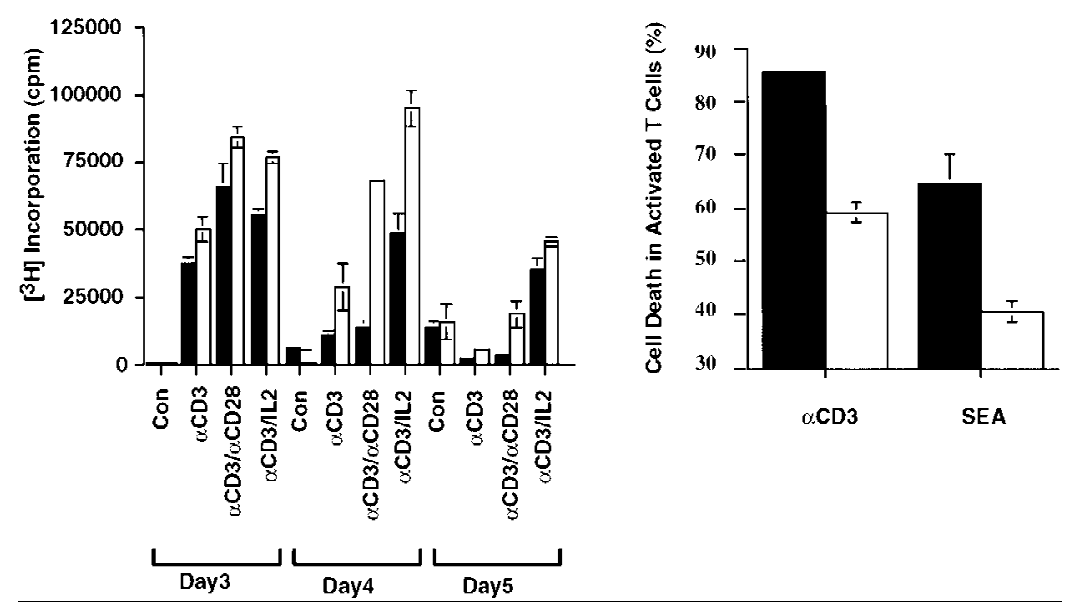

C
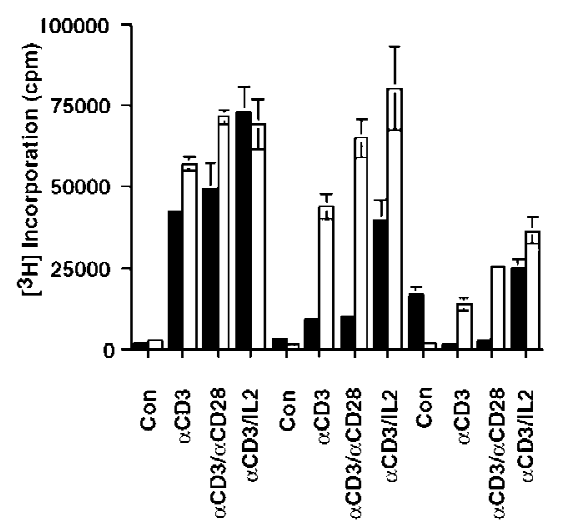

Day3
D

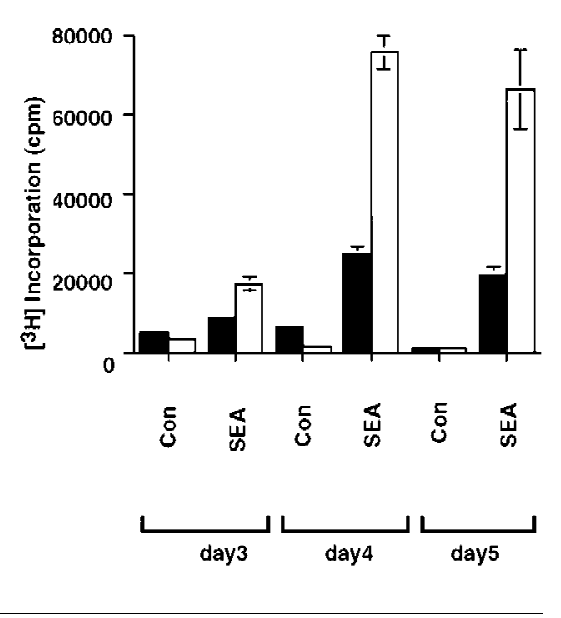

Figure 2. Reduced activation induced cell death in the absence of CPP32. (A,B) $\left[{ }^{3} \mathrm{H}\right]$ Thymidine uptake and cell death of stimulated CPP32 ${ }^{\text {wt }}$ and CPP32 ${ }^{\text {ex3-1-lym- }}$ phocytes. (C) $\left.{ }^{3} \mathrm{H}\right] \mathrm{Thymidine}$ uptake of stimulated $T$ cells from rag $2^{-1-}$ chimeric mice reconstituted with $\mathrm{CPP} 32^{\text {wt }}$ and CPP32 ${ }^{\text {ex } 3-1-E S}$ cells. (D) $\left[{ }^{3} \mathrm{H}\right]$ Thymidine uptake of SEA-stimulated Iymphocytes

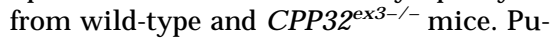
rified lymph node responder $T$ cells $\left(1 \times 10^{5}\right.$ cells/well) were activated with plate-bound anti-CD $3 \epsilon$ alone or with soluble anti-CD28 mAb or IL-2 (A,C), and SEA (D). After 3,4 , or 5 days of stimulation, $\left[{ }^{3} \mathrm{H}\right]$ thymidine uptake was determined. Similar experiments were performed with $1 \times 10^{6}$ lymph node cells cultured in 24-well tissue culture plates. At day 4 of stimulation, cells were harvested and the percentage of cell death was determined as indicated in $M$ aterials and $M$ ethods (B). Each panel shows results representative of at least four independent experiments. Solid bars represent CPP $32^{\text {wt }}$ cells; open bars represent CPP $32^{\text {ex3-1- }}$ cells. cells, respectively). Similar differences were seen following induction of cell death with anti-CD 95; (29\% vs $42 \%$ viable cells in CPP $32^{\mathrm{ex}+1-}$ and CPP $32^{\mathrm{e} \times 3-1-} \mathrm{T}$ cells, respectively). M orphological changes were seen also that contribute to the importance of CPP32 in these cells (discussed in detail in another section of this paper). These results indicate that CPP32 makes an essential contribution to apoptosis in peripheral T cells.

\section{CPP32 expression is not required for cytotoxic killing of target cells}

Cytotoxic $T$ Iymphocytes (CTLs) lyse target cells in a contact-dependent manner with two independent mechanisms. The first invol ves the secretion of the poreforming protein perforin onto the target cell, whereas the second requires the interaction of Fas ligand on the effector cell with Fas on the surface of the target cell. It is thought that secreted granzymes, a family of serine proteases colocalizing with perforin in the cytoplasmic granules of CTLs, participate in the first pathway in in- ducing target cell death. Granzyme B is the main candidate for this function because of its ability to process and activate several caspases in vitro, including CPP32, ICELAP3 (caspase 7), and ICE-LAP6 (caspase 9) (Darmon et al. 1995, 1996; Chinnaiyan et al. 1996; Duan et al. 1996; Quan et al. 1996).

To determine whether the expression of CPP32 in the target cell is required for sensitivity to the perforindependent pathway of $\mathrm{T}$ cell-mediated cytotoxicity, CPP32 ${ }^{\text {ex3-1- }}$ and heterozygous control MEFs were label ed with a LCMV-GP-derived epitope peptide and used as target cells for LCMV-specific CTLs. Both types of target cells showed a similar level of ${ }^{51} \mathrm{Cr}$ rel ease when incubated with CTLs from C57BL/ 6 mice (Fig 3). These results indicate that CPP32 is not required for target cell Iysis with CTLs.

\section{CPP32 involvement in bone marrow neutrophil apoptosis}

Neutrophils play a major role in inflammatory re 


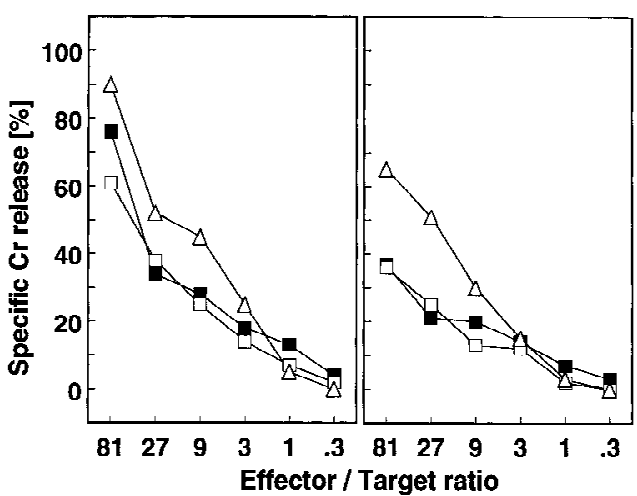

Figure 3. Cytotoxic killing of target cells in the absence of CPP32. CPP32 $2^{\mathrm{ex}-1-}(\square)$ and CPP32 ${ }^{\mathrm{ex} 3}$ heterozygous MEFs ( $\square$ ), as well as control M C57G cells $(\triangle)$ were labeled with a LCMVGP derived epitope peptide and used as target cells for LCMVspecific CTLs derived from C57BL/ 6 mice. Different effector/ target cell ratios were tested. ${ }^{51} \mathrm{Cr}$ release was determined after $5 \mathrm{hr}$ incubation of target cells with effector cells.

sponses, and their clearance by apoptosis is required to prevent inflammatory damage of tissues (Liles 1997). To determine whether CPP32 is required for neutrophil apoptosis, bone marrow (BM) neutrophils from mutant and wild-type mice were treated with cycloheximide (CHX). CHX has been shown previously to induce neutrophil apoptosis (Tsuchida et al. 1995). CPP32 $2^{\text {ex-1- BM }}$ neutrophils showed a significant resistance to cell death induced with $\mathrm{CHX}$ treatment (Fig. 4). Therefore, CPP32 expression is required for $\mathrm{CHX}$-induced apoptosis in $\mathrm{BM}$ neutrophils.

CPP32-deficient ES cells are resistant to UV-irradiation and osmotic shock-induced apoptosis

The rol e of CPP32 in mediating apoptosis in ES cells was addressed by use of two independent CPP32 $2^{\mathrm{e} 3-1-} \mathrm{ES}$ clones. CPP32 ${ }^{\text {ex } 3-1-}$ and wild-type ES cells were treated with several apoptotic stimuli, including UV-irradiation, $\gamma$-irradiation, sorbitol, and heat shock. Cell viability was monitored by either staining with annexin $\mathrm{V}$ and $\mathrm{PI}$, or by trypan blue exclusion. No differences in apoptosis were observed between the mutant and wild-type ES cells in response to $\gamma$-irradiation (Fig. 5A) or heat shock (data not shown). In response to UV-irradiation or osmotic shock following sorbitol treatment, however, CPP $32^{\mathrm{e} \times 3-1-E S}$ cells showed high resi stance to apoptosis compared with wild-type controls (Fig. 5B,C). Western bl ot analysis showed that in ES cells, CPP32 is processed in response to UV-irradiation but not $\gamma$-irradiation (data not shown). These results indicate that, in ES cells, CPP32 is necessary for UV-irradiation and sorbitol induced apoptosis, but not apoptosis induced by heat shock or $\gamma$-irradiation.

Reduced cell death in oncogenically transformed MEFs lacking CPP32

Many anticancer drugs exert their effects by inducing tumor cell apoptosis (M esner et al. 1997). Therefore, the chemosensitivity of tumor cells and consequently, the ability of a genotoxic agent influence to tumor devel opment, are control led by a precisely organized sequence of caspase activation. To examine the requirement of CPP32 for programmed death of oncogenically transformed cells, we used an experimental system on the basis of the proapoptotic activity of E1A and ras oncogenes. Primary MEFs transformed with E1A and Ras oncoproteins become sensitive to several apoptosis-inducing stimuli, including $\gamma$-irradiation, serum withdrawal, mTN F $\alpha$ and several chemotherapeutic drugs (Lowe et al . 1993; Lanni et al. 1997; McC urrach et al. 1997; Samuelson et al. 1997). Therefore, by introducing E1A and Ras into MEFs obtained from control and knockout mutant mice, it is possible to examine the requirement for the deleted gene during apoptosis induced by different agents.

With this objective, early passage MEFs from wildtype and CPP32 $2^{\mathrm{ex}}-1-$ knock out mice were transformed with EIA and ras oncogenes by retroviral gene transfer, and the resulting cell populations were examined for viability following treatment with the apoptotic stimuli described above. As can be seen in Figure 6, both the time response $(A-C)$ and the sensitivity $(D-F)$ to these agents were compromised in E1A/Ras-transformed CPP32 $2^{\text {ex3-1-MEFs. }}$

To demonstrate that the apoptotic defects of the CPP32 $2^{\text {ex } 3-1-}$ MEFs were a direct consequence of the CPP32 deficiency rather than the result of variations in the genetic background, a wild-type CPP32 gene was reintroduced into E1A/ras MEFs by retroviral gene transfer. Overexpression of CPP32 was not toxic itself, be cause it did not induce spontaneous cell death or any of the hallmarks of apoptosis (data not shown). On treatment with apoptotic stimuli, however, CPP32 $2^{\text {ext-1- }}$ cells expressing exogenously transfected CPP32 died at levels

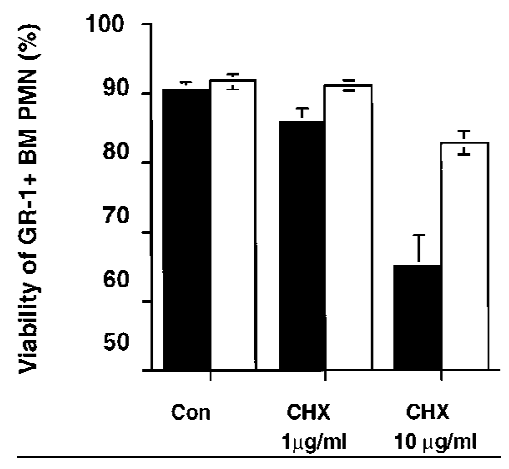

Figure 4. BM neutrophil apoptosis in the absence of CPP32. $\mathrm{BM}$ neutophils were incubated with medium alone (Con), or with $\mathrm{CHX}(1$ or $10 \mu \mathrm{g} / \mathrm{ml})$. After $3 \mathrm{hr}$ incubation, cells were harvested and the viability of BM neutrophils was assessed by analysis of 7-AAD ${ }^{+} \mathrm{GR}-1^{+}$cells. Solid bars represent wild-type mice; open bars represent CPP32-deficient mice. Data show mean \pm S.E.M. for 10 animals in each group, analyzed in three separate experiments. CPP32-deficient BM neutophils display significantly less cell death after incubation with $10 \mu \mathrm{g} / \mathrm{ml}$ of $\mathrm{CHX}$ than do wild-type cells. 


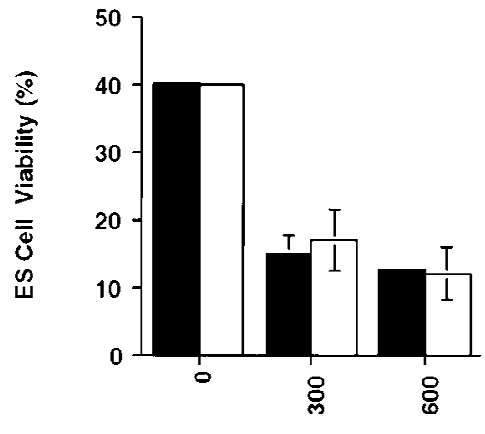

$\gamma$ irradiation (rads)

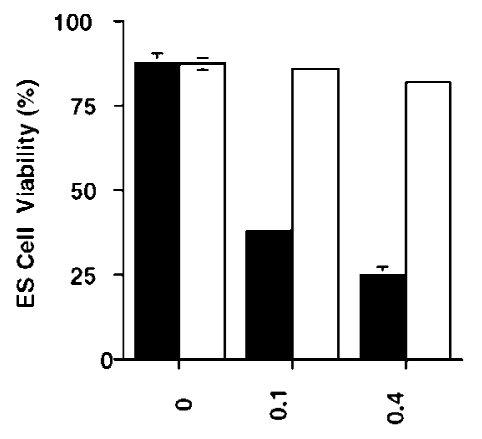

Sorbitol (mM)

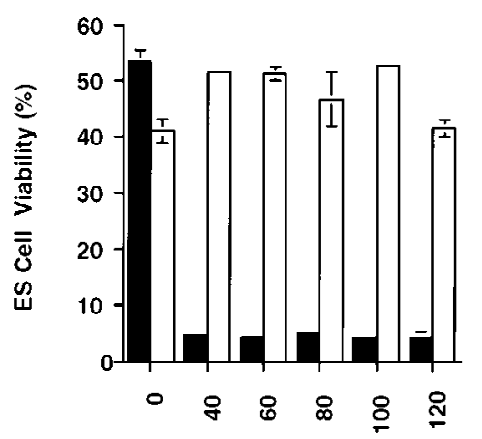

UV-irradiation $\left(j / m^{2}\right)$

Figure 5. Impaired apoptosis in mutant CPP32 ${ }^{\mathrm{ex} 3-1-}$ ES cells. Induction of cell death in CPP32 $2^{\mathrm{ex} 3+-}$ and two different CPP32 ${ }^{\mathrm{ex} 3-1-\text { ES }}$ cell clones by $\gamma$-irradiation (A), sorbitol (B), and UV irradiation (C). Unstimulated controls are al so shown. Cells were harvested after the indicated stimulus and analyzed for cell viability with flow cytometry PI and Annexin V-FITC costaining. Similar results were obtained in three different experiments. (Solid bars) CPP32 ${ }^{\mathrm{wt}}$; (open bars) CPP $32^{\mathrm{ex}}{ }^{-1-}$.

similar to cells harboring only endogenous CPP32 (Fig. $6 \mathrm{G}-\mathrm{I})$. Hence, exogenous CPP32 rescued the cell death defect of CPP32 $2^{\text {ex }-1-M E F s . ~}$

\section{A berrant apoptosis select cell types lacking CPP32}

CPP32 was initially considered the major caspase responsible for the proteolytic processing of poly(ADP-ribase) polymerase (PARP) ( $\mathrm{N}$ ichol son et al. 1995; Tewari et al . 1995; for review, see Thornberry et al . 1997). CPP32 also has been implicated in other aspects of apoptosis, including external ization of PS, various morphological changes, and ol igonucleosomal DN A degradation (Liu et al. 1997; Rudel et al. 1997). To examine the requirement for CPP32 in these processes, E1A/Ras wild type and CPP $32^{\text {ex3 }-1-}$ MEFs were treated as indicated above, and dying cells were examined for caspase activation, PARP cleavage, changes in PS distribution, chromatin structure and DN A degradation. As a control, the same cells were treated with bleach to induce necrosis.

In wild-type M EFs expressing E1A and Ras, adriamycin treatment induced CPP32 processing (Fig. 7A) and proteolysis of PARP into 89- and 24-kD fragments (Fig. 7B). Similar results were obtained upon MTN F $\alpha$ and serum withdrawal (Fig. 7C; data not shown). By use of an affinity probe (biotin-DEVD-amk) known to recognize acti ve caspases (Thornberry 1994; Takahashi et al. 1996), a dramatic decrease in total caspase activation in CPP32 ${ }^{\text {ex } 3-1-}$ cells was observed (not shown). PARP, however, was still processed in CPP32 $2^{\mathrm{e} 3-1-}$ cells treated with adriamycin, $\mathrm{mTNF} \alpha$, or serum deprivation to an extent proportional to the number of dead cells (Fig. 7B,C). In contrast, CPP32 was not activated on bleach treatment (Fig. 7A) and PARP was completely absent (Fig. 7B), presumably owing to general protein degradation. Thus, CPP32 is not required for PARP processing in E1A/Ras-transformed cells.
To assess the contribution of CPP32 to membrane changes during apoptosis, the distribution of PS was analyzed by Annexin V-FITC and PI staining. Consistent with the cell viability data, CPP32 $2^{\text {ex-1- }}$ cells displayed an increased annexin V-negative population compared with their wild-type counterparts, (45\% vs. $15 \%$ respectively; cf. bottom left quadrants in Fig. 7D), indicating a reduction in cell death. A substantial number of CPP32 $2^{\text {ex3-1- }}$ cells, however, were Annexin V-positive but PI-negative (bottom right quadrants of Fig. 7D), indicating binding of Annexin $V$ to cells with intact plasma membranes. This staining pattern is indicative of PS relocalization to the outer plasma membrane, a fundamental characteristic that distinguishes apoptosis from necrosis.

To examine nuclear changes during apoptosis following various apoptotic stimuli, oncogenically transformed MEFs, ES cells, and peripheral T cells were analyzed. E1A/Ras-transformed M EFs deficient for CPP32 showed marked defects in chromatin condensation and DNA degradation following treatment with various apoptotic stimuli. DAPI staining revealed that dying E1A/Rastransformed CPP32 $2^{\text {ex3-1- }}$ cells did not display the collapsed chromatin pattern characteristic of apoptosis that was clearly evident in wild-type cells (Fig. 8A). Furthermore, dying CPP $32^{\text {ex3-1-M }}$ EFs displayed a complete absence of oligonucleosomal DNA fragments, or ladders when analyzed by agarose gel el ectrophoresis. Reintroduction of exogenous CPP32 restored normal patterns of chromatin condensation and DNA degradation in CPP32 ${ }^{\mathrm{e} 33-1-}$ cells treated with apoptotic agents (Fig. 8B; data not shown), indicating that CPP32-deficiency was directly responsible for these defects.

Similar observation of nuclear changes were seen in peripheral T cells fol lowing UV irradiation and foll owing death induction with CD3E or Fas antibody (Fig. 9A). Both chromatin condensation and DNA laddering were 
Woo et al.
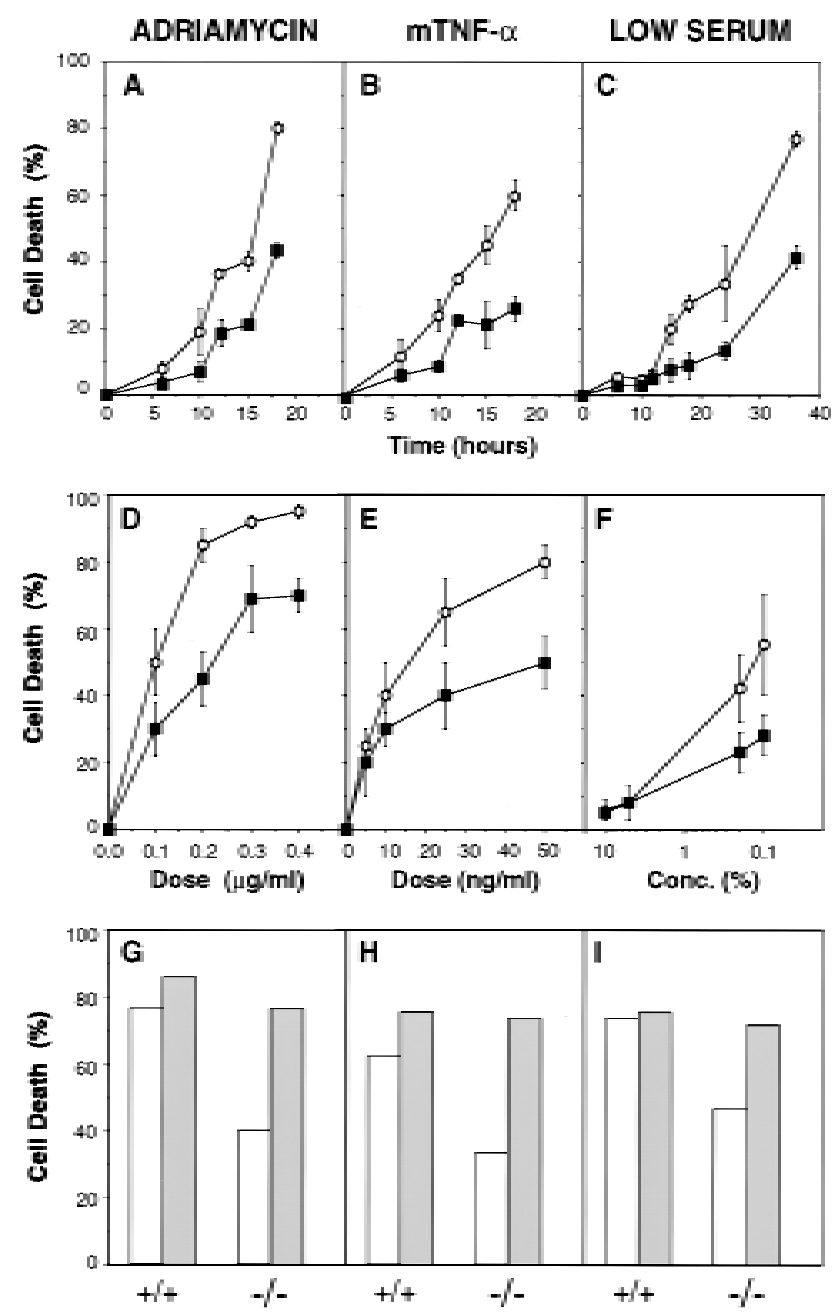

Figure 6. Reduced chemosensitivity of E1A/Ras-transformed MEFs in the absence of CPP32 and its restoration by reintroduction of wild-type CPP32. (A,C) Wild-type (O) and CPP32 $2^{\text {ex } 3-1-(\square) ~ M E F s ~ w e r e ~ t r e a t e d ~ w i t h ~ a ~ s i n g l e ~ d o s e ~ o f ~ a d r i a-~}$ mycin $(0.2 \mu \mathrm{g} / \mathrm{ml})(A), \mathrm{mTNF}_{\alpha}(50 \mathrm{ng} / \mathrm{ml})(B)$, or serum withdrawal $(0.2 \% \mathrm{FCS})(\mathrm{C})$, and collected at the indicated times. Cell death was determined by a trypan blue exclusion assay. (D-F) Response of 13S/Ras MEFs to $24 \mathrm{hr}$ treatment with increasing amounts of adriamycin (D), mTNF- $\alpha(E)$, and with decreasing amounts of serum $(\mathrm{F}) .(\mathrm{O})$ Wild type; $(\mathbf{\square})$ CPP32 $2^{\mathrm{ex}-1}-$. Each point represents the mean \pm S.D. from three independent experiments. (G-I) Effect of introduction of wild-type CPP32 (shaded bars) on the cell death response of the 13S/Ras MEFs. The effect of the pWZLHygro vector (open bars) on both wild-type and CPP $32^{\text {ex }}{ }^{-1-}$ cells is al so shown as a control. Data correspond to the percentage of dead cells scored at $18 \mathrm{hr}$ after treatment with $0.2 \mu \mathrm{g} / \mathrm{ml}$ adriamycin (G), $50 \mathrm{ng} / \mathrm{ml} \mathrm{mTNF} \alpha(\mathrm{H})$, or serum withdrawal $(0.2 \%$ FCS $)(\mathrm{I})$.

not seen in untreated $T$ cells, but following apoptosis induction with anti-CD $3 \epsilon$ and anti-CD95, distinct chromatin condensation was seen in $T$ cells from wild-type mice but incomplete chromatin condensation was seen in the mutant $T$ cells (Fig. 9A,B).

In ES cells, CPP32 was selectively dispensable for $\gamma$ but not UV-irradiated cells as mentioned in the previous section. In keeping with this observation, chromatin condensation was seen only following $\gamma$ - (data not shown) but not following UV-irradiation in CPP32 ${ }^{\mathrm{e} 3-1-}$

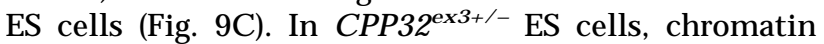
showed clear condensation following UV-irradiation, but in CPP32 ${ }^{\text {ex3 }-1-}$ ES cells, there was abnormal chromatin condensation in which chromatin remained diffuse in the nucleus. As well, DNA laddering was seen only in the CPP32 $2^{\text {ex3+1- ES cells and absent in the CPP32 }} 2^{\text {ex3-1- }}$ ES cells (data not shown).
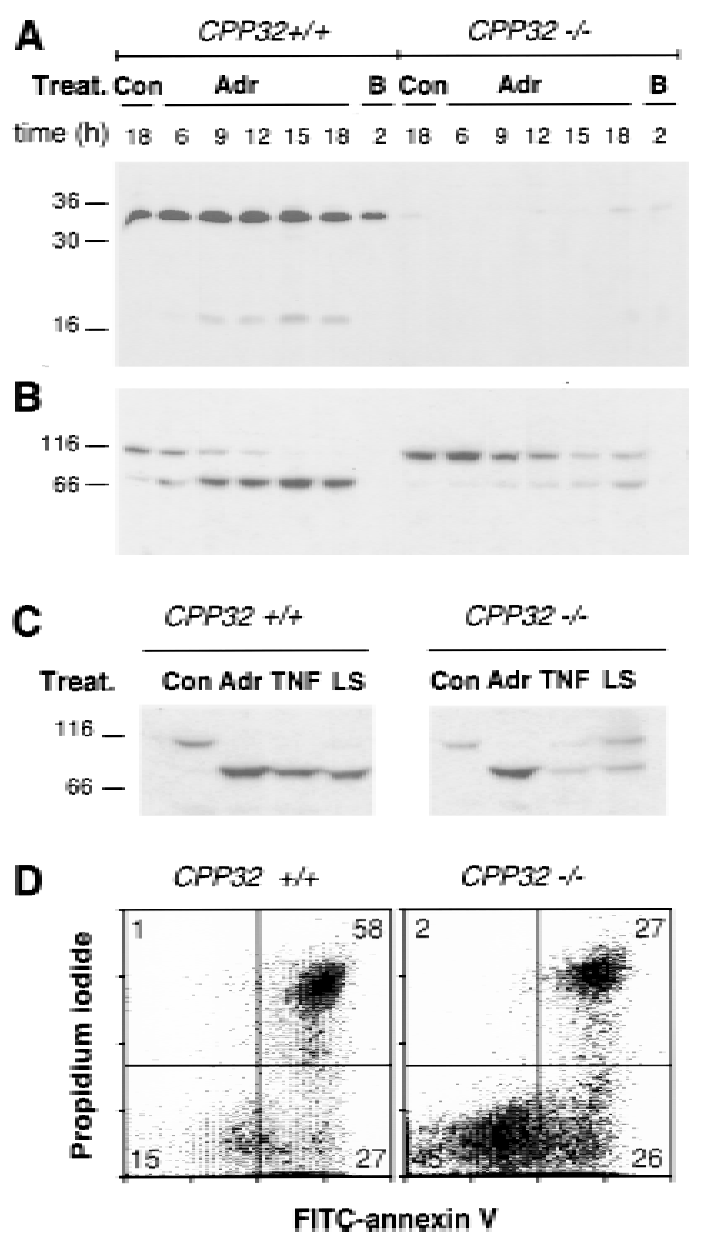

Figure 7. A poptotic-like processing of PARP and loss-of-membrane phospholipid asymmetry in cell death in the absence of CPP32. (A,B) 13S/Ras MEFs of the indicated genotype were not treated as control (Con) or treated with adriamycin $0.2 \mu \mathrm{g} / \mathrm{ml}$ (Adr). The time courses of CPP32 processing (A) and PARP (B) are shown. As a control for events occurring in necrotic cells, both wild-type and CPP32 ${ }^{\text {ex } 3-1-}$ MEFs were placed for $2 \mathrm{hr}$ in $0.5 \%$ bleach (B). (C) CPP32 is not essential for PARP cleavage following adriamycin $(0.2 \mu \mathrm{g} / \mathrm{ml}, 24 \mathrm{hr}), \mathrm{mTN} \mathrm{F}-\alpha(50 \mathrm{ng} / \mathrm{ml}, 24$ $\mathrm{hr}$ ) or low serum $(0.2 \%, 36 \mathrm{hr})$ treatments of $13 \mathrm{~S} /$ Ras MEFs. (D) Fluorescence dot blots of FITC-Annexin V and PI stained 13S/ Ras wild-type and CPP32 ${ }^{\text {ex }}-1-$ MEFs incubated for $24 \mathrm{hr}$ in medium with $0.2 \%$ serum. In both cell types, cell death occurs with changes in the plasma membrane that lead to the exposure of phosphotydil serine, allowing interaction (and therefore, staining) with Annexin V (right). PI staining (top right) is indicative of late stages of cell death. 


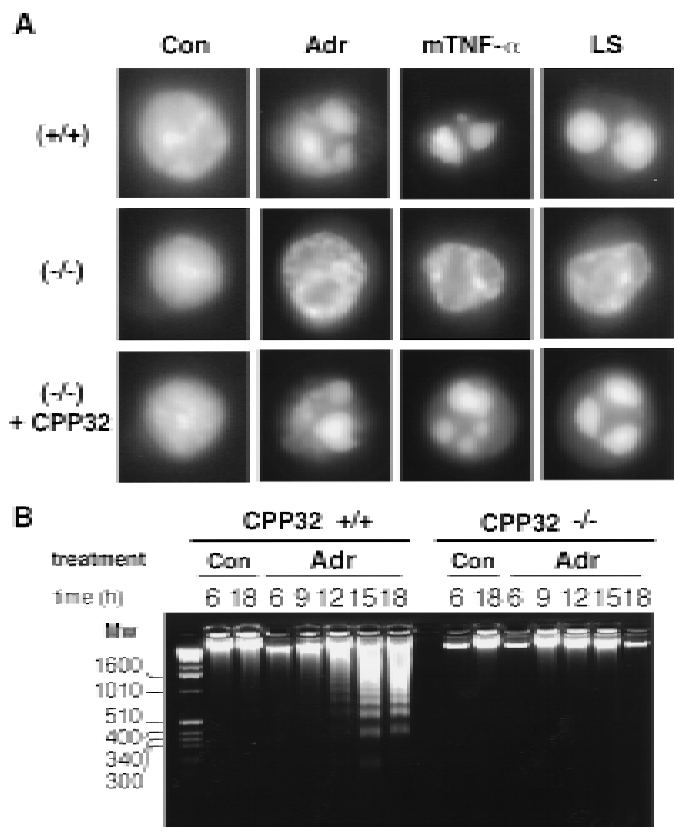

Figure 8. Abnormal chromatin condensation and absence of oligonucleosomal DNA degradation in dying CPP32 $2^{\text {ex }-1-13 S / ~}$ Ras MEFs. (A) Fluorescence microscopy visualization of DAPI staining of DNA from wild-type $(+t)$, and CPP32 $2^{\text {ex } 3-t-}(-t-)$ MEFs untreated control (Con) or treated with $0.2 \mu \mathrm{g} / \mathrm{ml}$ adria-

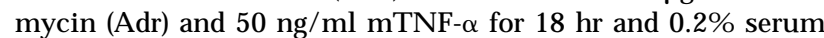
(LS) for 36 hr. Chromatin condensation in CPP32 $3-1-$ did not progress to a fully collapsed state, and no apoptotic bodies were observed on any of the treatments tested. (B) DNA extracted from untreated control (Con) and adriamycin-treated $(0.2 \mu \mathrm{g} /$ $\mathrm{ml}$ ) wild-type and CPP32 ${ }^{\text {ex3-1- } 13 S / R a s ~ M E F s . ~ A f t e r ~ t r e a t m e n t, ~}$ wild-type MEFs display the classical laddering degradation of DNA; the laddering does not occur in the CPP32 $2^{\text {ex }-1-}$ cells.

Electron microscopy of apoptotic M EFs and peripheral $T$ cells confirmed that the absence of CPP32 resulted in aberrant chromatin condensation (Fig. 10 and data not shown). CPP32 ${ }^{\mathrm{ex} 3-1-}$ cells were highly vacuolized, contained swollen mitochondria, and appeared incapable of completely breaking down various cellular organelles. Although some of these characteristics are suggestive of necrotic cell death, the ability of CPP32 ${ }^{\text {ex } 3-1-}$ cells to cleave PARP and redistribute PS strongly suggests that, in sel ect cell types, CPP32 deficiency results in an aberrant form of apoptosis.

These observations seen in multiple cell systems enforce the specific role of CPP32 in specific cell systems in a stimulus-dependent manner.

\section{Discussion}

A great deal of our understanding of the regulation of apoptosis comes from studies of lower order organisms such as worms (C. elegans) and fruit flies (Drosophila melanogaster). Whereas apoptosis in these species may be induced by many different signals (White 1993), there is evidence that distinct pathways can lead to a common apoptotic program. For example, apoptosis in response to
A
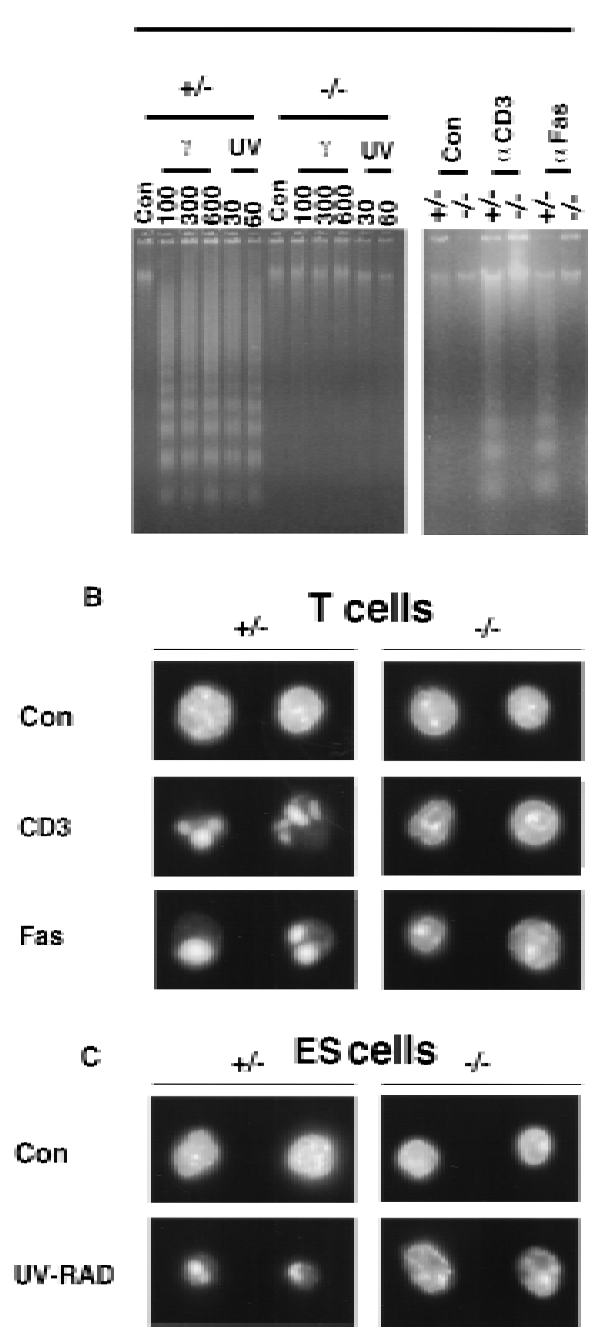

Figure 9. Absence of DNA laddering and abnormal chromatin condensation in dying peripheral activated CPP32 $2^{\mathrm{e} 3-1-} \mathrm{T}$ cells and ES cells. (A) DNA was extracted from CPP32 $2^{\mathrm{e} 3+1-}$ and CPP32 $2^{\text {ex } 3-1-}$ peripheral $\mathrm{T}$ cells untreated control (Con), and treated with UV- and $\gamma$-irradiation at 100,300 , and 600 rads and 30 and $60 \mathrm{~J} / \mathrm{m}^{2}$, respectively. DN A laddering is seen in the wildtype group but not in CPP32 ${ }^{\mathrm{e} 33-1-\mathrm{T}}$ cells. Activated peripheral $\mathrm{T}$ cells were al so treated for $48 \mathrm{hr}$ with anti-CD $3 \epsilon$ and anti-Fas anti bodies. M utant cells showed absence of DN A ladder formation following apoptotic stimuli. (B) Fluorescence microscopy visualization of DAPI staining of DNA from peripheral T cells and ES cells. CPP32 $2^{\mathrm{e} 3+1-}$ and CPP32 $2^{\mathrm{e} 3-1-}$ activated peripheral $\mathrm{T}$ cells were treated with anti-CD $3 \epsilon$, and anti-Fas for $48 \mathrm{hr}$ and fixed in $5 \%$ paraformal dehyde and stained with DAPI. In wildtype $\mathrm{T}$ cells, normal chromatin condensation is seen, but in CPP32 $2^{\text {ex } 3-1-} \mathrm{T}$ cells, clear and complete chromatin condensation is not seen. CPP32 $2^{\mathrm{e} 3+1-}$ and CPP32 $2^{\mathrm{e} 3-1-}$ ES cells were al so stained with DAPI following no treatment control (Con) and 24 $\mathrm{hr}$ after UV-irradiation (UV-RAD) at $60 \mathrm{~J} / \mathrm{m}^{2}$. In untreated control (Con) section, no chromatin condensation is seen in both CPP $32^{\mathrm{e} \times 3+1-}$ and CPP $32^{\mathrm{e} \times 3-1-}$ group. Following UV-irradiation, chromatin is condensed in CPP32 $2^{\mathrm{ex} 3+1-}$ ES cells, but clear and complete chromatin condensation is not seen in CPP32 $2^{\text {ex } 3-1-E S}$ cells. 


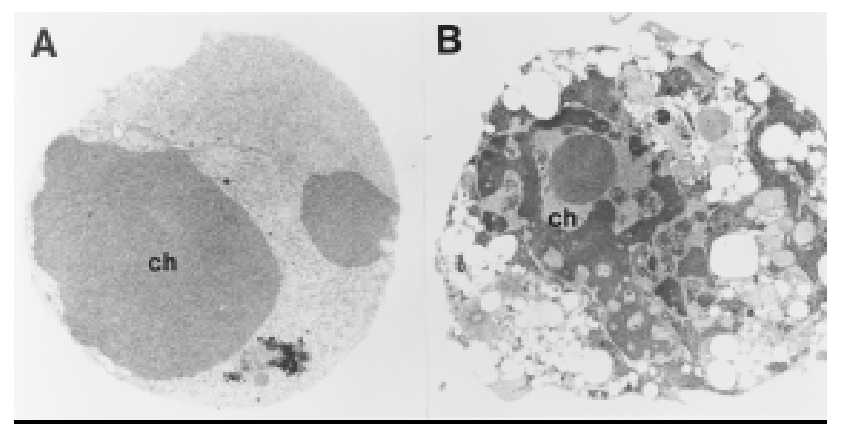

Figure 10. Electron microscopy of dead wild-type (A) and CPP32 $2^{\text {ex }-1-}$ (B) $13 S /$ Ras MEFs. Cells were treated with adriamycin $(0.2 \mu \mathrm{g} / \mathrm{ml})$ for $24 \mathrm{hr}$ and processed for el ectron microscopy visualization as described in Materials and Methods. Shown are thin sections of nonadherent (presumably dying) cells that become detached (dead) after treatment. $N$ ote the aberrant chromatin (ch) condensation and vacuolization of the mutant CPP32 ${ }^{\text {ex3-1-MEFs. }}$

many different death-inducing signals is inhibited by the expression of Bcl2 or baculovirus p35 (Clem et al. 1991; Sugi moto et al. 1994; Armstrong et al. 1996). In addition, the Drosophila gene reaper encodes a protein capable of integrating information from different signaling pathways and converging them in the activation of what appears to be a single apoptotic program. On the basis of these and other observations, it has been proposed that the machinery for PCD is mediated by one common mechanism (Hale et al. 1996).

In the mammalian system, the complexity of the organism has required the evolution of a large number of ICE homologs as the effectors of cell death. Therefore, it is not a simple task to understand how the death machinery is regulated in higher species. Different apoptotic stimuli can have very different effects on cell growth and viability depending on the tissue origin (Kastan et al. 1992; Clarke et al. 1993; Lowe et al. 1993). Furthermore, even within the same cell type, the sensitivity to a given apoptotic stimulus can be altered by developmental stage or by oncogenic mutation (Lowe et al. 1993; Clayton et al. 1997). Despite this diversity, the morphological features of apoptotic cell death are remarkably constant, suggesting that a similar convergence of death signals on a single apoptotic program might apply equally well to mammalian systems.

CPP32 is consi dered to be a prototypical caspase and a key effector of PCD (Fernandes-AInemri et al. 1994; $\mathrm{Ni}$ chol son et al. 1995; Tewari et al. 1995; Casciol a-Rosen et al. 1996). Given this view, it was surprising that an earlier report on the effects of CPP32 mutation in mice cited only defects in neuronal apoptosis (Kuida et al. 1996). In this study, we used mice, ES cells, and MEFs deficient for CPP32 to assess the role of CPP32 in apoptosis in a wide variety of biological and physiological settings. By taking a comprehensive approach, we have demonstrated the fundamental contribution of CPP32 to many forms of apoptosis. We have also demonstrated that CPP32 is involved in several other systems besides the nervous system, and that it influences the PCD of peripheral Iymphoid cells, neutrophils, ES cells and embryonic fibroblasts.

The consequences of CPP32 deficiency are remarkably context-dependent, with apoptotic defects being both tissue- and stimulus-specific. Moreover, in some settings, CPP32 loss affects some hallmarks of apoptosis but not others. These findings lead us to conclude that the notion of common apoptotic machinery is too simplistic. The apoptotic machinery may be as complex and diverse as the stimuli that activate cell death.

\section{Tissue-specific consequences of CPP32 inactivation}

The expression of CPP32 in thymocytes and immature B cells, and its processing in response to several stimuli, suggested a role for this caspase in the PCD of these cells. A poptosis of immature $T$ and $B$ cells has a major role in building the mature $T$ and $B$ cell repertoires (Smith et al. 1989; Hartley et al. 1993). Studies of the role of CPP32 in immature thymocyte apoptosis (this study and Kuida et al. 1996) as well as in immature B cell apoptosis have indicated that CPP32 is dispensable for PCD in these cells. In contrast, more differentiated cells in the T cell lineage, such as peripheral T cells, showed dependence on CPP32 expression for normal AICD. This tissue-specific requirement for CPP32 in apoptosis was also observed in ES cells, and in oncogenically transformed MEFs. Thus, in contrast to thymocytes, absence of CPP32 expression resulted in ES cells resistant to UVirradiation-induced apoptosis. These results suggest that, in most tissues and in response to most apoptotic stimuli, there are multiple caspases present that are either redundant in function or acting in concert with one another. In certain cases, however, such as in ES cells following UV-irradiation or osmotic shock, no other caspase can compensate for the absence of CPP32, making it an indispensable caspase.

\section{Stimuli-specific involvement of CPP32} within the same cell type

It has been demonstrated that the apoptotic machinery can be activated by increased levels of p53. DN A breaks caused by $\gamma$-irradiation, the presence of DNA repair intermedi ates from UV-irradiation, and other stress signals such as hypoxia or drugs have all been shown to increase levels of p53 (Lowe et al. 1993; Lee et al. 1995; M artin et al. 1995; Graeber et al. 1996). The upstream pathways leading to CPP32 processing and activation have not been well characterized, but the above findings have led to the postulation that p53 is upstream of ICE/ced3 family of proteases. In this study we show that CPP32 re sponds differentially to several different cell-damaging stimuli. CPP32 $2^{\mathrm{e} 3-1-E S}$ cells were resistant to apoptosis induced by UV-irradiation but susceptible to cell death induced by $\gamma$-irradiation.

The stimuli-specific involvement of CPP32 within the same cell type was also well established by use of oncogenically transformed MEFs. In these cells, CPP32 is re- 
quired for normal apoptosis following treatment with TNF $\alpha$, adriamycin, or serum deprivation, but not in response to CTL killing. These results indicate that apoptosis regulation is a compl ex process and that upstream pathways leading to CPP32 activation can be surprisingly distinct, even in response to similar treatments.

\section{Aberrant apoptosis select cell types}

CPP32 appears to have specific tasks in apoptosis. CPP32 deficiency delays apoptosis in E1A/ras-transformed MEFs following treatment with several stimuli, and,

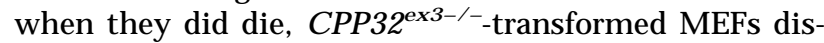
played some hallmarks of apoptosis but not others. In particular, PARP cleavage and PS relocalization to the outer leaflet of the plasma membrane occurred as expected, but the chromatin was neither properly condensed nor the DNA degraded. In addition, these cells appeared to be incapable of completely breaking down cellular organelles. These defects were also seen in CPP32 ${ }^{\text {ex } 3-1-}$ peripheral $\mathrm{T}$ cells and ES cells following various apoptotic stimuli highlighting a consistent pattern of the important role that CPP32 has in nuclear events in apoptosis. Two proteins, DNA fragmentation factor (DFF) and p21-activated kinase 2 (PAK2), were reported recently to be targets for activated CPP32 (Liu et al. 1997; Rudel et al. 1997). These proteins are both activated in response to apoptotic stimuli and have been shown to induce DN A fragmentation. A possible defect in the expression or the activation of either DFF or PAK2 might explain the absence of nuclear condensation and DNA fragmentation in the mutant CPP32 ${ }^{\mathrm{ex} 3}$ cells, and this possibility is under investigation. Other activated caspases were detected with biotinylated tetrapeptide

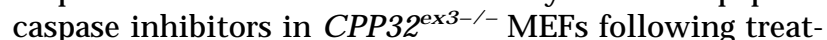
ment with apoptotic stimuli. Moreover, at least one other known caspase (caspase 7) is processed in CPP32deficient cells undergoing cell death (data not shown). Taken together, these results provide the first direct evidence that, in some situations, multiple caspases work in concert to bring about the complete biochemical and morphological changes characteristic of apoptotic cell death.

\section{Redundancy vs. specificity}

CPP32 has been shown to be activated in many forms of cell death, but the fact that apoptosis can proceed in the absence of CPP32 argues that either other caspases can compensate for CPP32, or that the caspases are redundant in function. Inhibitors of the ICE-CED3 family have been shown to inhibit thymocyte apoptosis (Clayton et al. 1997), but the absence of CPP32 expression does not lead to deleterious effects in thymocytes, indicating that in these cells, other caspases can play compensatory roles. This study has reveal ed a large number of circumstances, however, in which a loss of CPP32 leads to defective apoptosis that cannot be relieved by other caspases, showing that the role of CPP32 in apoptosis is remarkably context-dependent. Therefore, de- spite the fact that most apoptotic programs produce similar morphological and biochemical endpoints, the route to these endpoints can be highly variable, even at the level of the apoptotic machinery.

Much investigation has focused on the consequences of CPP32 activation during apoptosis. Our results imply that it is not possible to generalize the role of specific caspases to all cell types or all stimuli. This specificity may have important implications for antiapoptotic therapies. In particular, because apoptosis is essential for many mammalian processes, global inactivation of the apoptotic machinery might have deleterious consequences for the entire organism. Our data argue, however, that inhibition of a central caspase can have context-dependent effects on apoptosis, raising the possibility that inhibitors of specific caspases will show specificity for certain forms of cell death.

In this study, we have shown for the first time that CPP32 is required in multiple systems and cell types in a context-specific manner. We have also demonstrated that CPP32 is specifically required for sel ective morphological changes during apoptosis. This CPP32 mutant animal model allows a detailed assessment of the complex cell death process and more importantly, will lead to more focused examinations and possible therapeutic studies of human diseases such as AIDS and cancer.

\section{Materials and methods}

Cells

E14K ES cells from 129/Ola mice were maintained on a layer of mitomycin C-treated embryonic fibroblasts in Dulbecco's modified Eagle culture medium (DMEM), supplemented with leukemia inhibitory factor, 15\% fetal calf serum (FCS), L-glutamine, and $\beta$-mercaptoethanol.

Generation of CPP32 ${ }^{\mathrm{ex} 3}$ mutant mice

A 129/J mouse genomic library was screened with a CPP32 mouse CDNA probe. Three overlapping phage genomic clones were isolated and included CPP32 exons 2-4. A targeting vector was designed to replace a 910-bp genomic fragment containing CPP32 exons 3 with the PGKneo resistance expression cassette. The targeting vector $(20 \mu \mathrm{g})$ was linearized with $\mathrm{Kpnl}$ and electroporated into E14K ES cells $\left(5 \times 10^{6}\right)$ (Bio-Rad Gene Pulser, $0.34 \mathrm{kV}, 0.25 \mathrm{mF}$ ). The cells were subsequently cultured in the presence of $300 \mu \mathrm{g} / \mathrm{ml} \mathrm{G} 418$ (Sigma) for 10 days. Homologous recombinants were identified by PCR. An external primer specific for the CPP32 gene upstream of the targeting construct (5'-TCTATTTGTTCAGTGTTGGAT-3') and a primer specific for the neo cassette (5'-TCATTCTCAGTATTGTTTTGC-3') were used in the PCR analysis. Colonies positive by PCR were genotyped by Southern blotting of HindllI-digested DNA and hybridized with random hexamer $\left[{ }^{32} \mathrm{P}\right] \mathrm{dCTP}$-labeled DNA probes (Amersham). An EcoR1 600-bp CPP32 external probe, and a neo specific probe, were used for hybridization. Three correctly targeted colonies were identified.

Chimeric mice were produced by microinjection of targeted ES cells into 3.5-day C57BL/6 blastocysts that were transferred to $C D 1$ pseudopregnant foster mothers. Chimeric males were mated with C57BL /6 J females (Jackson Laboratories), and germline transmission of the mutant allele was verified by PCR and 
Southern blot analysis of tail DN A from $F_{1}$ offspring with agouti coat color. Two injected ES colonies contributed to the germ line of mice. F2 offspring from heterozygous intercrosses were genotyped by Southern blotting. Mutant mice derived from the two targeted ES cells showed the same phenotype.

Generation of CPP32 ${ }^{\text {ex3 }}$ Homozygous ES cells and rag2 mutant chimera

Two different CPP32 $2^{\text {ex3H- }}$ ES clones were cultured at an increased concentration of G418. At $0.6 \mathrm{mg} / \mathrm{ml} \mathrm{G} 418,>90 \%$ of the colonies died. Colonies that were resistant to $0.6 \mathrm{mg} / \mathrm{ml}$ G418 were analyzed for homologous recombination of the second allele by PCR with primers to detect the deleted portion of the CPP32 gene (5'-CCTCAGGTGCCAGTCATCCAT- 3 ' and 5'-CCATACATGGGAGCAAGTCAG-3'). Colonies that were homozygous by PCR for the CPP32 ${ }^{\text {ex3 }}$ mutation were expanded and their genotype confirmed by Southern blot analysis. The second allele was inactivated in $\sim 4 \%$ of ES cells resistant to 0.6 $\mathrm{mg} / \mathrm{ml} \mathrm{G} 418$. The two homozygous CPP32 $2^{\mathrm{ex}} \mathrm{ES}$ clones were injected into rag $2^{-1-}$ blastocysts and chimeric mice were generated as described previously.

\section{A poptotic induction of peripheral T cells}

Activation-induced cell death Lymph node cells and splenocytes $\left(1 \times 10^{5}\right)$ from wild-type or CPP32 ${ }^{\text {ex3 }}$ mutant mice were incubated in 96-well round bottom plates (N unc, Kamptrop, Denmark) in $200 \mu \mathrm{l}$ of HL-1 medium (Hycor Biomedical Inc, Irvine, CA) supplemented with $2 \mathrm{~mm}$ glutamine, $50 \mathrm{~m} \beta$-mercaptoethanol, penicillin, streptomycin, and $2 \%$ FCS. Cells were stimulated by the addition of superantigen SEA $(5 \mu \mathrm{g} / \mathrm{ml})$ or 50 $\mathrm{U} / \mathrm{ml}$ of recombinant mouse IL2 (Genzyme, Cambridge, MA). For stimulation with cross linked anti-CD $3 \epsilon$ antibodies, and plates were coated with polyclonal rabbit anti-hamster antibodies (Jackson Laboratories) at $10 \mu \mathrm{g} / \mathrm{ml}$ in PBS at $4^{\circ} \mathrm{C}$ overnight. Plates were washed with PBS and incubated for $3 \mathrm{hr}$ with antiCD $3 \epsilon$ mAb (clone: 145-2C11; PharMingen) at $1 \mu \mathrm{g} / \mathrm{ml}$ in PBS and washed again with PBS. After the indicated time of culture, $1 \mu \mathrm{Ci}$ / well of $\left[{ }^{3} \mathrm{H}\right]$ thymidine (NEN, Boston, $\mathrm{MA}$ ) was added to the cell cultures. After a subsequent $12-18 \mathrm{hr}$ of culture, cells were harvested (Filtermate-196 harvester; Canberra Packard, $\mathrm{M}$ ississauga, Canada) and $\left[{ }^{3} \mathrm{H}\right]$ thymidine incorporation was determined (M atrix-96 direct $\beta$ counter, Canberra Packard).

Parallel experiments were performed with $1 \times 10^{6}$ lymph node cells cultured in 24 well tissue culture plates. At day 4 of stimulation, cells were harvested and percentage of cell death was determined by Annexin V and PI staining with flow cytometry. Cells were also counted with hemocytometer by trypan blue exclusion.

CD36- and CD95-mediated apoptosis Lymphocytes from CPP32 $2^{\text {ex }+1-}$ and CPP32 $2^{\text {ex3-1- }}$ mice were isolated and cultured in plate bound anti-CD $3 \epsilon(10 \mu \mathrm{g} / \mathrm{ml})$ for $24 \mathrm{hr}$ and then cultured in Con A (10\%) for 4 days. Then, the activated lymphocytes were treated with either plate bound anti-CD $3 \in(10 \mu \mathrm{g} / \mathrm{ml})$ or antiCD95 $(1 \mu \mathrm{g} / \mathrm{ml})$ for $48 \mathrm{hr}$. Cells were then analyzed for Annexin $\mathrm{V}$ and PI staining as well as prepared for DAPI staining and for DNA laddering as described below.

BM neutrophil apoptosis

BM cells were harvested from the femurs of wild-type or CPP32 $2^{\text {ex }-1-}$ mutant mice by flushing with $2 \mathrm{ml}$ of RPMI containing 10\% FCS. Cells from each mouse were pooled, washed, and resuspended at $10 \times 10^{6} \mathrm{cells} / \mathrm{ml}$ in RPMI containing $10 \%$ FCS. BM cells $\left(2 \times 10^{6}\right)$ were incubated at $37^{\circ} \mathrm{C}$ in a final volume of $1 \mathrm{ml}$ in round-bottomed 5-ml polypropylene tubes containing medium al one, or medium containing $\mathrm{mTNF}-\alpha(10 \mathrm{ng} / \mathrm{ml})$ or cycloheximide $(1 \mu \mathrm{g} / \mathrm{ml}$ or $10 \mu \mathrm{g} / \mathrm{ml})$. After $3 \mathrm{hr}$ incubation, cells were harvested and the viability of $B M$ neutrophils was assessed by analysis of $7-\mathrm{AAD}^{+} \mathrm{GR}-\mathrm{I}^{+}$cells. M onoclonal antibodies used for FACS analysis were Mac-1 FITC and GR-1 PE (both PharM ingen). By use of a gate on $\mathrm{M} \mathrm{ac}-1^{+} / \mathrm{GR}-1^{+}$cells, the viability of BM neutrophils was determined by analysis of 7AAD-positive cells specifically in this population.

\section{ES cell death induction}

One heterozygous and two homozygous CPP32 ${ }^{\text {ex3 }}$ ES cell clones $\left(1 \times 10^{5}\right)$ were plated on $1 \%$ gelatinized plates ( 24 well plates; Costar) in ES cell media. Twenty-four hours after the initial plating at $37^{\circ} \mathrm{C}$, the following cell death stimuli were given: UV-irradiation at $40,60,80,100$, and $120 \mathrm{~J} / \mathrm{m}^{2}$ with DNA Stratalinker (Stratagene), $\gamma$-irradiation at 300,600 , and 1000 rads (Gammacell 40 Exactor); $0.1 \mathrm{~mm}$ and $0.4 \mathrm{~m}$ sorbito; low serum at $0.1 \% \mathrm{FCS}$; and heat shock $\left(43^{\circ} \mathrm{C}\right.$ for $\left.30 \mathrm{~min}\right)$. The same number of cells was also grown at $37^{\circ} \mathrm{C}$ as a control. Cell counts were determined on days 1, 2, 3, and 4 after the initial induction of cell death, by use of hemocytometer and trypan blue exclusion.

ES cells were al so harvested 24 and $48 \mathrm{hr}$ after the induction of cell death for FACS analysis to detect apoptotic and viable cells. ES cells were resuspended in $200 \mu \mathrm{l}$ of PBS-1\% BSA and incubated with $10 \mu$ l of Annexin V-FITC and $10 \mu \mathrm{l}$ of PI at room temperature for $20 \mathrm{~min}$. Four hundred microliters of buffer, provided by the manufacturer ( $R \& D$ Systems), was added and viable cells were quantitated by flow cytometry.

\section{Generation of CPP32 $2^{\mathrm{e} 3-1-}$ primary MEFs}

Primary MEFs derived from wild-type and CPP32 $32^{\text {ex }-1-}$ day 12.5 embryos were prepared as described previously (Serrano et al. 1997). All cultures were maintained in DMEM (GIBCO) supplemented with $10 \%$ FCS and $1 \%$ penicillin G/streptomycin sulfate (Sigma).

\section{Retrovirus-mediated gene transfer}

Ecotropic retroviruses were produced by the Phoenix packaging line (generously provided by G. N olan, Stanford U niversity, CA) according to a previously described calcium phosphate precipitation method (McCurrach et al. 1997; Serrano et al. 1997). Transformation of wild-type and CPP32 $2^{\text {ex } 3-1-}$ MEFs was achieved by sequential infections (Serrano et al. 1997) with the following retroviral vectors: pLPC-13S that coexpresses 135 E1A CDNA with puromycin phosphotransferase, and pWZLRas/CD8, coexpressing human $\mathrm{H}$-ras V12 CDN A with the CD8 cell surface marker. Infected pLPC-13S cells were selected in medium containing $2.5 \mu \mathrm{g} / \mathrm{ml}$ puromycin (Sigma) and after infection with pWZL-Ras/CD8, cells were recovered with magnetic beads conjugated to anti-CD8 (Dynal).

For analyzing the effects of ectopic expression of CPP32, CPP32 cDN A was subcloned into pWZLHygro, a retroviral vector expressing hygromycin phosphotransferase. Selection of infected cells was performed in medium containing $100 \mu \mathrm{g} / \mathrm{ml}$ hygromycin B (Boehringer Mannheim).

Programmed cell death in 13S/Ras MEFs

Induction of cell death Cells $\left(3 \times 10^{6}\right.$ to $\left.4 \times 10^{6}\right)$ were plated in $10-\mathrm{cm}$ plates ( 2 plates per treatment). After $8 \mathrm{hr}$, cells were 
washed twice with PBS and treated with the indicated amounts of adriamycin (Sigma) or mTNF $\alpha$ (Boehringer Mannheim) in DMEM-10\% FCS. The effect of serum withdrawal was analyzed by placing the cells in DMEM supplemented with different amounts of FCS. At the indicated times, adherent and nonadherent cells were pooled and prepared for the various cell death

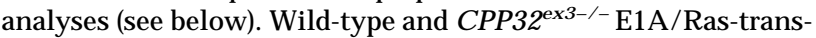
formed MEFs were treated with $0.5 \%$ bleach for the indicated time ( $2 \mathrm{hr}$ ), collected and processed for caspase labeling and Western bl ot analysis as indicated for adriamycin, TNF, and low serum treatments. The amount of dead cells on bleach treatment, as estimated by trypan blue exclusion, was $90 \pm 5 \%$ for both cell types. $\mathrm{N}$ uclei analysis of bleach-treated MEFs by DAPI staining did not show apoptotic-like chromatin condensation.

Cell viability Approximately $1 \times 10^{5}$ cells were collected for trypan blue exclusion analysis and scored within $1 \mathrm{hr}$ after stopping treatment. At least 200 cells were counted for each point. The percentage of dead cells was also determined by flow cytometric analysis by use of PI and Annexin V-FITC costaining according to the manufacturer's (R \& D Systems) instructions.

PARP processing Approximately $2 \times 10^{6}$ cells were washed with PBS, pelleted, and frozen at $70^{\circ} \mathrm{C}$. Cells were lysed in N P$40 \%$ lysis buffer ( $1 \% \mathrm{~N} \mathrm{P}-40,150 \mathrm{~mm} \mathrm{~N} \mathrm{aCl}, 50 \mathrm{~mm}$ Tris- $\mathrm{HCl}$ at $\mathrm{pH}$ 8.0, $1 \mathrm{~mm}$ sodium vanadate) supplemented with protease inhibitor cocktail $(0.1 \mathrm{~mm} \mathrm{PMSF}, 10 \mu \mathrm{g} / \mathrm{ml}$ of cytochal asin $\mathrm{B}, 2$ $\mu \mathrm{g} / \mathrm{ml}$ of chymostatin, leupeptin, antipain, and pepstatin) for 60 min on ice. Lysates were centrifuged at 10,000 rpm for $5 \mathrm{~min}$ at $4^{\circ} \mathrm{C}$, and protein concentration was estimated by the Bio-Rad protein assay with BSA as the standard. Thirty micrograms of total protein was loaded onto 10\% SDS-PAGE and transferred to an Immobilon-P membrane (Millipore). Western blot analysis was carried out according to standard procedures by ECL detection. PARP antibody and the secondary antibody, horseradish peroxidase-conjugated sheep anti-mouse, were both used at a 1:1000 dilution.

DNA fragmentation analysis Approximately $3 \times 10^{6}$ treated cells were washed in cold PBS, pelleted and frozen at $-70^{\circ} \mathrm{C}$. Total DNA was extracted by overnight incubation at $4^{\circ} \mathrm{C}$ in 0.5 $\mathrm{ml}$ of lysis buffer $(50 \mathrm{~mm}$ Tris- $\mathrm{HCl}$ at $\mathrm{pH} 7.5,10 \mathrm{~mm}$ EDTA at $\mathrm{pH} 8.0,200 \mathrm{~mm} \mathrm{NaCl}, 1 \% \mathrm{NP}-40,50 \mathrm{ng} / \mathrm{ml}$ of freshly added proteinase K). Lysates were centrifuged at $5000 \mathrm{rpm}$ for $10 \mathrm{~min}$ at $4^{\circ} \mathrm{C}$. DN A was recovered by standard phenol-chloroform extraction and ethanol precipitation. Dry pellets were resuspended in $50 \mu \mathrm{g} / \mathrm{ml}$ TE-RN ase and incubated at $37^{\circ} \mathrm{C}$ for 30 min. Samples were loaded on to a $1.5 \%$ native agarose gel and visualized by $\mathrm{EtBr}$ staining.

Visualization of chromatin condensation Approximately $1 \times 10^{5}$ cells were fixed in $5 \%$ paraformal dehyde (M allinckrodt) and DN A was stained with DAPI $(1 \mu \mathrm{g} / \mathrm{ml})$. Images of the condensation state of the chromatin were taken with a fluorescence microscope coupled to a Photometrics PXL CCD camera (Photometrics Ltd.)

Analysis of cell death by electron microscopy Adherent cells were rinsed twice in $1 \times$ PBS, and fixed in $0.2 \mathrm{M}$ cacodylate buffer/3\% glutaral dehyde for $30 \mathrm{~min}$. $\mathrm{N}$ onadherent cells were lightly pelleted and embedded in 3\% agar following fixation. The fixation was removed with three rinses in $0.2 \mathrm{M}$ cacodylate. Samples were then postfixed in $1 \% \mathrm{OsO}_{4}$ in $0.1 \mathrm{~m}$ cacodylate for $1 \mathrm{hr}$, rinsed once in $\mathrm{dH}_{2} \mathrm{O}$, dehydrated through a graded ethanol series, and embedded in epon-araldite. Thin sections were cut on a Reichert UItracut E, picked up on copper grids, and poststained with uranyl acetate and Reynold's lead citrate. Grids were examined and photographed in a Hitachi H-7000 TEM.

\section{Acknowledgments}

We thank the technical support of Julia Potter, Drew Wakeham, Annick Itie, Christine Mirtsos, Antonio Ruiz de la Vera, Denis Bouchard, Suzanne Plyte, and M ary Saunders for scientific editing. Electron microscopy was done with hel p of D. Spector. We also thank J. Rodrigues for the CPP32 retroviral vector, Raffick Sekaly for CPP32 antibody and Y. Lazebnik for helpful advice. M.S. is supported by a postdoctoral fellowship from the Spanish Ministry of Education and Human Frontiers Science Foundation. S.W.L. is a Kimmel Scholar. This research was supported by grants CA 13106 from the $\mathrm{N}$ ational Cancer Institute (S.W.L.) and by the $\mathrm{N}$ ational Cancer Institute of Canada (T.W.M ).

The publication costs of this article were defrayed in part by payment of page charges. This article must therefore be hereby marked "advertisement" in accordance with 18 USC section 1734 solely to indicate this fact.

\section{References}

Akbar, A.N. and M. Salmon. 1997. Cellular environments and apoptosis: Tissue microenvironments control activated $\mathrm{T}$ cell death. Immunol. Today 18: 72-76.

Alnemri, E.S., D.J. Livingston, D.W. Nicholson, G. Salvesen, N.A. Thornberry, W.W. Wong, and J. Yuan. 1996. Human ICE/CED-3 protease nomenclature. Cell 87: 171.

Armstrong, R.C., T. Aja, J. Xiang, S. Gaur, J.F. Krebs, K. Hoang X. Bai, S.J. Korsmeyer, D.S. Karanewsky, L.C. Fritz, and K.J. Tomaselli. 1996. Fas-induced activation of the cell deathrelated protease CPP32 is inhibited by $\mathrm{BCl}-2$ and by ICE family protease inhibitors. J. Biol. Chem. 271: 16850-16855.

Casciola-Rosen, L., D.W. Nicholson, T. Chong, K.R. Rowan, N.A. Thornberry, D.K. Miller, and A. Rosen. 1996. A popain/ CPP32 cleaves proteins that are essential for cellular repair: A fundamental principle of apoptotic. J. Exp. Med. 183: 1957-1964.

Chinnaiyan, A.M., W.L. Hanna, K. Orth, H. Duan, G.G. Poirier, C.J. Froelich, and V.M. Dixit. 1996. Cytotoxic T-cell-derived granzyme B activates the apoptotic protease ICE-LAP3. Curr. Biol. 6: 897-899.

Clarke, A.R., C.A. Purdie, D.J. Harrison, R.G. Morris, C.C. Bird, M.L. Hooper, and A.H. Wyllie. 1993. Thymocyte apoptosis induced by p53-dependent and independent pathways. Nature 362: 849-852.

Clayton, L.K., Y. Ghendler, E. Mizoguchi, R.J. Patch, T.D. Ocain, K. Orth, A.K. Bhan, V.M. Dixit, and E.L. Reinherz. 1997. T-cell receptor ligation by peptide/ M HC induces activation of a caspase in immature thymocytes: The molecuIar basis of negative selection. EMBO J. 16: 2282-2293.

Clem, R.J., M. Fechheimer, and L.K. Miller. 1991. Prevention of apoptosis by a baculovirus gene during infection of insect cells. Science 254: 1388-1390.

Darmon, A.J., D.W. Nicholson, and R.C. Bleackley. 1995. Activation of the apoptotic protease CPP32 by cytotoxic T-cellderived granzyme B. Nature 377: 446-448.

Darmon, A.J., T.J. Ley, D.W. Nicholson, and R.C. Bleackley. 1996. Cleavage of CPP32 by granzyme $B$ represents a critical role for granzyme $B$ in the induction of target cell DNA fragmentation. J. Biol. Chem. 271: 21709-21712.

Duan, H., K. Orth, A.M. Chinnai yan, G.G. Poirier, C.J. Froelich, 
W.W. He, and V.M. Dixit. 1996. ICE-LAP6, a novel member of the ICE/Ced-3 gene family, is activated by the cytotoxic $T$ cell protease granzyme B. J. Biol. Chem. 271: 16720-16724.

Fadok, V.A., D.R. Voelker, P.A. Campbel I, J.J. Cohen, D.L. Bratton, and P.M. Henson. 1992. Exposure of phosphatidylserine on the surface of apoptotic lymphocytes triggers specific recognition and removal by macrophages. J. Immunol. 148: 2207-2216.

Faleiro, L., R. Kobayashi, H. Fearnhead, and Y. Lazebnik. 1997. Multiple species of CPP32 and Mch2 are the major active caspases present in apoptotic cells. EMBO J. 16: 2271-2281.

Fernandes-Alnemri, T., G. Litwack, and E.S. Alnemri. 1994. CPP32, a novel human apoptotic protein with homology to Caenorhabditis el egans cell death protein Ced-3 and mammalian interleukin-1 $\beta$-converting enzyme. J. Biol. Chem. 269: 30761-30764.

Goldberg, Y.P., D.W. Nicholson, D.M. Rasper, M.A. Kalchman, H.B. Koide, R.K. Graham, M. Bromm, P. Kazemi-Esfarjani, N .A. Thornberry, J.P. Vaillancourt, and M.R. Hayden. 1996. Cleavage of huntingtin by apopain, a proapoptotic cysteine protease, is modulated by the polyglutamine tract. Nature Genet. 13: 442-449.

Graeber, T.G., C. Osmanian, T. Jacks, D.E. Housman, C.J. Koch, S.W. Lowe, and A.J. Giaccia. 1996. Hypoxia-mediated selection of cells with diminished apoptotic potential in solid tumours. Nature 379: 88-91.

Green, D.R. and S.J. Martin. 1995. The killer and the executioner: How apoptosis controls malignancy. Curr. O pin. Immunol. 7: 694-703.

Hale, A.J., C.A. Smith, L.C. Sutherland, V.E. Stoneman, V. Longthorne, A.C. Culhane, and G.T. Williams. 1996. A poptosis: Molecular regulation of cell death. Eur. J. Biochem. 237: 884 .

Hartley, S.B., M.P. Cooke, D.A. Fulcher, A.W. Harris, S. Cory, A. Basten, and C.C. Goodnow. 1993. Elimination of selfreactive $B$ Iymphocytes proceeds in two stages: Arrested development and cell death. Cell 72: 325-335.

Hengartner, M.O. 1996. Programmed cell death in invertebrates. Curr. Opin. Genet. Dev. 6: 34-38.

Hengartner, M.O. and H.R. Horvitz. 1994a. Programmed cell death in Caenorhabditis elegans. Curr. Opin. Genet. Dev. 4: $581-586$.

- - . 1994b. C. elegans cell survival gene ced-9 encodes a functional homolog of the mammalian proto-oncogene bcl2. Cell 76: 665-676.

Kastan, M.B., Q. Zhan, W.S. el-Deiry, F. Carrier, T. Jacks, W.V. Walsh, B.S. Plunkett, B. Vogelstein, and A.J. Fornace, Jr. 1992. A mammalian cell cycle checkpoint pathway utilizing p53 and GADD45 is defective in ataxia-telangiectasia. Cell 71: 587-597.

Kuida, K., T.S. Zheng, S. N a, C. Kuan, D. Yang, H. Karasuyama, P. Rakic, and R.A. Flavell. 1996. Decreased apoptosis in the brain and premature lethality in CPP32- deficient mice. Nature 384: 368-372.

Lanni, J.S., S.W. Lowe, E.J. Licitra, J.O. Liu, and T. Jacks. 1997. p53-independent apoptosis induced by paclitaxel through an indirect mechanism. Proc. Natl. Acad. Sci. 94: 9679-9683.

Lee, S., B. Elenbaas, A. Levine, and J. Griffith. 1995. p53 and its $14 \mathrm{kDa}$-terminal domain recognize primary DNA damage in the form of insertion/deletion mismatches. Cell 81: 1013-1020.

Liles, C.W. 1997. Apoptosis-role in infection and inflammation. Curr. Opin. Infect. Dis. 10:165-170.

Liu, X., H. Zou, C. Slaughter, and X. Wang. 1997. DFF, a heterodimeric protein that functions downstream of caspase-3 to trigger DNA fragmentation during apoptosis. Cell
89: $175-184$.

Lowe, S.W., H.E. Ruley, T. Jacks, and D.E. Housman. 1993. p53-dependent apoptosis modulates the cytotoxicity of anticancer agents. Cell 74: 957-967.

Lowe, S.W., E.M. Schmitt, S.W. Smith, B.A. Osborne, and T. Jacks. 1993. p53 is required for radiation-induced apoptosis in mouse thymocytes. Nature 362: 847-849.

M artin, S.J., D.D. N ewmeyer, S. M athias, D.M. Farschon, H.G. Wang, J.C. Reed, R.N. Kolesnick, and D.R. Green. 1995. Cell-free reconstitution of Fas-, UV radiation- and ceramideinduced apoptosis. EMBO J. 14: 5191-5200.

McCurrach, M.E., T.M. Connor, C.M. Knudson, S.J. Korsmeyer, and S.W. Lowe. 1997. Bax-deficiency promotes drug resistance and oncogenic transformation by attenuating p53-dependent apoptosis. Proc. Natl. Acad. Sci. 94: 2345-2349.

Mesner, P.W., Jr., I.I. Budihardjo, and S.H. Kaufmann. 1997. Chemotherapy-induced apoptosis. Adv. Pharmacol. 41: 461-499.

N agata, S. 1997. A poptosis by death factor. Cell 88: 355-365.

Nicholson, D.W., A. Ali, N.A. Thornberry, J.P. Vaillancourt, C.K. Ding, M. Gallant, Y. Gareau, P.R. Griffin, M. Labelle, Y.A. Lazebnik et al. 1995. Identification and inhibition of the ICE/CED-3 protease necessary for mammalian apoptosis. N ature 376: 37-43.

Nishina, H., K.D. Fischer, L. Radvanyi, A Shahinian, R. Hakem, E.A. Rubie, A. Bernstein, T.W. Mak, J.R. Woodgett, and J.M. Penninger. 1997. Stress-signalling kinase Sek 1 protects thymocytes from apoptosis mediated by CD 95 and CD3. Nature 385: 350-353.

Quan, L.T., M. Tewari, K. O'Rourke, V. Dixit, S.J. Snipas, G.G. Poirier, C. Ray, D.J. Pickup, and G.S. Salvesen. 1996. ProteoIytic activation of the cell death protease Yama/CPP32 by granzyme B. Proc. Natl. Acad. Sci. 93: 1972-1976.

Reed, J.C. 1997. Double identity for proteins of the Bcl-2 family. Nature 387: 773-776.

Rudel, T. and G.M. Bokoch. 1997. Membrane and morphological changes in apoptotic cells regulated by caspase-mediated activation of PAK2. Science 276: 1571-1574.

Samuelson, A.V. and S.W. Lowe. 1997. Selective induction of p53 and chemosensitivity in Rb-deficient cells by E1A mutants unable to bind the retinoblastsoma-related proteins. Proc. Natl. Acad. Sci. 94: 12094-12099.

Schmid, I., C.H. Uittenbogaart , J.V. Giorgi. 1994. Sensitive method for measuring apoptosis and cell surface phenotype in human thymocytes by flow cytometry. Cytometry 1: 1220.

Serrano, M., A.W. Lin, M.E. McCurrach, D. Beach, and S.W. Lowe. 1997. Oncogenic ras provokes premature cell senescence associated with accumulation of p53 and p16IN K4a. Cell 88: 593-602.

Smith, C.A., G.T. Williams, R. Kingston, E.J. Jenkinson, and J.J. Owen. 1989. Antibodies to CD3/T-cell receptor complex induce death by apoptosis in immature $\mathrm{T}$ cells in thymic cultures. Nature 337: 181-184.

Steller, H. 1995. Mechanisms and genes of cellular suicide. Science 267: 1445-1449.

Sugimoto, A., P.D. Friesen, and J.H. Rothman. 1994. Baculovirus p35 prevents developmentally programmed cell death and rescues a ced- 9 mutant in the nematode Caenorhabditis elegans. EMBO J. 13: 2023-2028.

Takahashi, A. and W.C. Earnshaw. 1996. ICE-related proteases in apoptosis. Curr. Opin. Genet. Dev. 6: 50-55.

Tewari, M., L.T. Quan, K. O'Rourke, S. Desnoyers, Z. Zeng, D.R. Beidler, G.G. Poirier, G.S. Salvesen, and V.M. Dixit. 1995. Yama/CPP32 beta, a mammalian homolog of CED-3, is a CrmA-inhibitable protease that cleaves the death sub- 
strate poly(ADP-ribose) polymerase. Cell 81: 801-809.

Thompson, C.B. 1995. A poptosis in the pathogenesis and treatment of disease. Science 267: 1456-1462.

Thornberry, N.A. 1994. Interleukin-1 beta converting enzyme. Methods Enzymol. 244: 615-631.

Thornberry, N.A., T.A. Rano, E.P. Peterson, D.M. Rasper, T. Timkey, M. Garcia-Calvo, V.M. Houtzager, P.A. N ordstrom, S. Roy, J.P. Vaillancourt, K.T. Chapman, and D.W. Nicholson. 1997. A combinatorial approach defines specificities of members of the caspase family and granzyme B. Functional relationships established for key mediators of apoptosis. J. Biol. Chem. 272: 17907-17911.

Tsuchida, H., Y. Takeda, H. Takei, H. Shinzawa, T. Takahashi, and F. Sendo. 1995. In vivo regulation of rat neutrophil apoptosis occurring spontaneously or induced with TN F-al pha or cycloheximide. J. Immunol. 154: 2403-2412.

Vaux, D.L. and A. Strasser. 1996. The molecular biology of apoptosis. Proc. Natl. Acad. Sci. 93: 2239-2244.

White, E. 1993. Death-defying acts: A meeting review on apoptosis. Genes \& Dev. 7: 2277-2284.

Xue, D., S. Shaham, and H.R. Horvitz. 1996. The Caenorhabditis el egans cell-death protein CED-3 is a cysteine protease with substrate specificities similar to those of the human CPP32 protease. Genes \& Dev. 10: 1073-1083.

Yang, Y., Z.H. Liu, C.F. Ware, and J.D. Ashwell. 1997. A cysteine protease inhibitor prevents activation-induced T-cell apoptosis and death of peripheral blood cells from human immunodeficiency virus-infected individuals by inhibiting upregulation of Fas ligand. Blood 89: 550-557.

Yuan, J., S. Shaham, S. Ledoux, H.M. Ellis, and H.R. Horvitz. 1993. The $C$. el egans cell death gene ced-3 encodes a protein similar to mammalian interleukin-1 $\beta$-converting enzyme. Cell 75: 641-652.

Zhou, H., W.J. Henzel, X. Liu, A. Lutschg, and X. Wang. 1997. A paf-1, a human protein homologous to $C$. elegans CED-4, participates in cytochrome c-dependent activation of caspase-3. Cell 90: 405-413. 


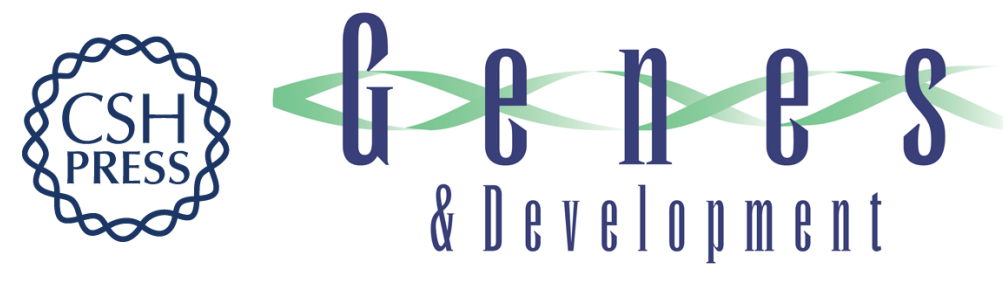

\section{Essential contribution of caspase 3/CPP32 to apoptosis and its associated nuclear changes}

Minna Woo, Razqallah Hakem, Maria S. Soengas, et al.

Genes Dev. 1998, 12:

References This article cites 54 articles, 22 of which can be accessed free at:

http://genesdev.cshlp.org/content/12/6/806.full.html\#ref-list-1

License

Email Alerting

Receive free email alerts when new articles cite this article - sign up in the box at the top

Service

right corner of the article or click here.

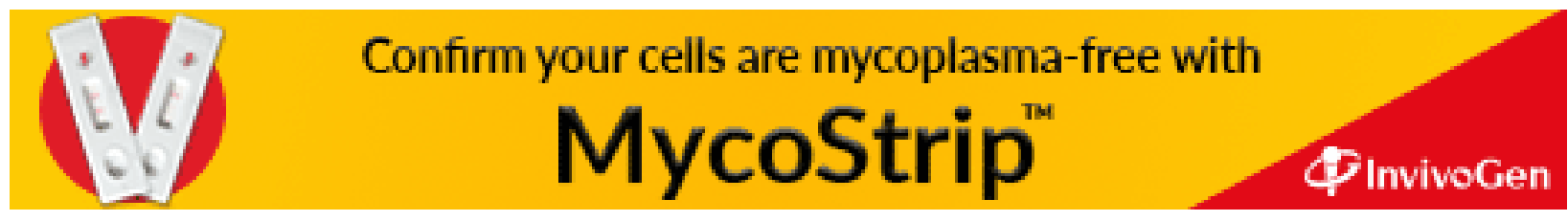

